\title{
Effect of Glucagon on Intracellular pH Regulation in Isolated Rat Hepatocyte Couplets
}

\author{
Domenico Alvaro, Paola Della Guardia, Adriano Bini, Alessandro Gigliozzi, Sonia Furfaro, Tiziana La Rosa, \\ Claudia Piat, and Livio Capocaccia \\ II Department of Gastroenterology, University of Rome "La Sapienza," Rome, Italy
}

\begin{abstract}
To elucidate mechanisms of glucagon-induced bicarbonaterich choleresis, we investigated the effect of glucagon on ion transport processes involved in the regulation of intracellular $\mathbf{p H}\left(\mathrm{pH}_{\mathrm{i}}\right)$ in isolated rat hepatocyte couplets. It was found that glucagon $(200 \mathrm{nM})$, without influencing resting $\mathrm{pH}_{\mathrm{i}}$, significantly stimulates the $\mathrm{CI}^{-} / \mathrm{HCO}_{3}^{-}$exchange activity. The effect of glucagon was associated with a sevenfold increase in cAMP levels in rat hepatocytes. The activity of the $\mathrm{Cl}^{-} / \mathrm{HCO}_{3}^{-}$exchanger was also stimulated by DBcAMP + forskolin. The effect of glucagon on the $\mathrm{Cl}^{-} / \mathrm{HCO}_{3}^{-} \mathrm{ex}-$ change was individually blocked by two specific and selective inhibitors of protein kinase A, Rp-cAMPS (10 $\mu M)$ and H-89 $(30 \mu \mathrm{M})$, the latter having no influence on the glucagon-induced cAMP accumulation in isolated rat hepatocytes. The $\mathrm{Cl}^{-}$channel blocker, NPPB $(10 \mu \mathrm{M})$, showed no effect on either the basal or the glucagon-stimulated $\mathrm{Cl}^{-} /$ $\mathrm{HCO}_{3}^{-}$exchange. In contrast, the protein kinase $\mathrm{C}$ agonist, PMA (10 $\mu \mathrm{M})$, completely blocked the glucagon stimulation of the $\mathrm{Cl}^{-} / \mathrm{HCO}_{3}^{-}$exchange; however, this effect was achieved through a significant inhibition of the glucagonstimulated cAMP accumulation in rat hepatocytes. Colchicine pretreatment inhibited the basal as well as the glucagon-stimulated $\mathrm{Cl}^{-} / \mathrm{HCO}_{3}^{-}$exchange activity. The $\mathrm{Na}^{+} / \mathrm{H}^{+}$ exchanger was unaffected by glucagon either at basal $\mathbf{p H}_{\mathbf{i}}$ or at acid $\mathrm{pH}_{\mathrm{i}}$ values. In contrast, glucagon, at basal $\mathrm{pH}_{\mathrm{i}}$, stimulated the $\mathrm{Na}^{+}-\mathrm{HCO}_{3}^{-}$symport. The main findings of this study indicate that glucagon, through the cAMP-dependent protein kinase A pathway, stimulates the activity of the $\mathrm{Cl}^{-} / \mathrm{HCO}_{3}^{-}$exchanger in isolated rat hepatocyte couplets, a mechanism which could account for the in vivo induced bicarbonate-rich choleresis. (J. Clin. Invest. 1995. 96:665-675.) Key words: glucagon $\cdot$ hepatocytes $\cdot \mathrm{Cl}^{-}$/ $\mathrm{HCO}_{3}^{-}$exchanger $\cdot \mathrm{cAMP} \cdot$ protein kinase $\mathrm{A}$
\end{abstract}

\section{Introduction}

Glucagon, in the liver, exerts a number of metabolic effects such as inhibition of glycogen synthesis and stimulation of gluconeogenesis and glycogenolysis.

Part of this work was presented at the American Gastroenterological Association Meeting in New Orleans on 15-18 May 1994 and was published in abstract form (1994. Gastroenterology. 106:858A).

Address correspondence to Domenico Alvaro, MD, II Department of Gastroenterology, University of Rome "La Sapienza," via Valsolda 45/i, 00141 Rome, Italy. Phone: 39-6-4453319; FAX: 39-6-4440806.

Received for publication 13 September 1994 and accepted in revised form 29 March 1995.

J. Clin. Invest.

(C) The American Society for Clinical Investigation, Inc.

0021-9738/95/08/0665/11 $\$ 2.00$

Volume 96, August 1995, 665-675
Moreover, glucagon, at physiological doses, induces a bicarbonate-rich choleresis in humans (1) as well as in many different animal species, including the guinea pig (2), dog (3), and rat (4). Mechanisms of glucagon choleresis are still unknown. It has been established recently (2) that glucagon choleresis: $(a)$ is canalicular in origin as it is associated with an increased clearance of erythritol and is not influenced by bile ductule proliferation; $(b)$ is mediated by the intracellular messenger cAMP but not by inositol phosphates nor by prostaglandin release; and $(c)$ requires an intact microtubular system (colchicine sensitivity).

Bile salt-independent bile flow is the result of active solute transport followed by osmotic water flow in bile canaliculi (5). Bicarbonate together with glutathione represents the main solute responsible for this fraction of bile flow (5). The ion transport processes underlying basal or hormonal-stimulated bicarbonate secretion in the hepatocyte are currently under investigation. Recent progress has been made in studies exploring intracellular $\mathrm{pH}\left(\mathrm{pH}_{\mathrm{i}}\right)$ regulation in isolated hepatocytes $(6-8)$. These studies identify the presence of an electroneutral $\mathrm{Na}^{+}$-independent $\mathrm{Cl}^{-}$/ $\mathrm{HCO}_{3}^{-}$exchanger $(7,8)$ which functions as a counterpoint to the acid extruding systems $\left(\mathrm{Na}^{+} / \mathrm{H}^{+}\right.$exchanger and $\mathrm{Na}^{+}$$\mathrm{HCO}_{3}^{-}$symport) (6) and which has been detected recently in the hepatocyte apical domain of human liver (9). The $\mathrm{Cl}^{-}$/ $\mathrm{HCO}_{3}^{-}$exchanger is present in all the bicarbonate-secreting epithelia (10-19). In biliary epithelium for example, this exchanger, functionally coupled with apically located $\mathrm{Cl}^{-}$channels, is stimulated by secretin, a hormone which induces a ductular bicarbonate-rich choleresis $(18,19)$. The role of the $\mathrm{Cl}^{-} / \mathrm{HCO}_{3}^{-}$exchanger in the generation of bile salt-independent bile flow has been supported recently by studies in the isolated perfused rat liver, where stimulation of this exchanger by intracellular alkalinization is followed by a bicarbonate-rich choleresis (20).

In an attempt to elucidate the mechanisms of glucagon choleresis, this study focuses on the effect of glucagon on the $\mathrm{H}^{+} /$ $\mathrm{HCO}_{3}^{-}$transport processes involved in $\mathrm{pH}_{\mathrm{i}}$ regulation in isolated rat hepatocyte couplets (IRHC). ${ }^{1}$ The main data emerging from this study demonstrate that glucagon, through the cAMP-dependent protein kinase A pathway, stimulates the activity of the $\mathrm{Cl}^{-} / \mathrm{HCO}_{3}^{-}$exchanger, a mechanism which could account for bicarbonate-rich choleresis induced by the hormone. Glucagon induces an upregulation of $\mathrm{pH}_{\mathrm{i}}$ regulatory mechanisms operating in the presence of bicarbonate since, besides the $\mathrm{Cl}^{-}$/ $\mathrm{HCO}_{3}^{-}$exchanger (acid loader), the $\mathrm{Na}^{+}-\mathrm{HCO}_{3}^{-}$symporter

1. Abbreviations used in this paper: BCECF-AM, 2,7-bis (carboxyethyl)-5(6)-carboxyl-fluorescein-acetomethylester; $\beta_{\mathrm{i}}$, intrinsic buffering power; DBcAMP, $N^{6}, 2^{\prime}$-O-dibutyryladenosine-3'-5'-cyclic monophosphate; DIDS, 4,4,diisothiocyano-2,2' disulfonic acid stilbene; $\mathrm{H}$ 89, $N$-[2-( $p$-bromocinnamyl-amino)ethyl]-5-isoquinolinesulfonamide $\mathrm{HCl}$; IRHC, isolated rat hepatocyte couplets; L-15, Liebowitz-15; NPPB, 5'-nitro-2'-(3-phenylpropyl-amino)-benzoate; Rp-cAMPS, Rpadenosine-3',5'-monophosphothioate. 
(acid extruder) was also stimulated by the hormone. We have also shown that glucagon stimulation of the $\mathrm{Cl}^{-} / \mathrm{HCO}_{3}^{-}$exchanger does not involve 5'-nitro-2'-(3-phenylpropyl-amino)benzoate (NPPB)-sensitive $\mathrm{Cl}^{-}$channels, is partially blocked by the microtubular inhibitor colchicine, and is completely inhibited by the protein kinase C agonist, PMA, which, however, significantly decreases the cAMP accumulation induced by the hormone.

\section{Methods}

Materials. Glucagon, collagenase A, bovine serum albumin, EDTA, penicillin/streptomycin, heparin, Hepes, $\mathrm{D}(+)$ glucose, insulin, soybean trypsin inhibitor (type I-s), amiloride, DMSO, deoxyribonuclease (DN25 ), nigericin, 4,4, diisothiocyano-2,2' disulfonic acid stilbene (DIDS), $\mathrm{Na}^{+}$-gluconate, $\mathrm{K}^{+}$-gluconate, hemicalcium gluconate, $N^{6}, 2^{\prime}$-O-dibutyryladenosine-3'-5'-cyclic monophosphate (DBcAMP), forskolin, PMA, and 3-isobutyl-1-methyl-xanthine (IBMX) were purchased from Sigma Chemical Co. (St. Louis, MO). 2,7,bis (carboxyethyl)-5(6)carboxy-fluorescein-acetomethylester (BCECF-AM) was obtained from Molecular Probes, Inc. (Eugene, OR). Liebowitz 15 (L-15), MEM, $\alpha$ MEM, L-glutamine, gentamicin, and fetal calf serum were obtained from Gibco Laboratories (Grand Island, NY). NPPB was provided by Prof. R. Greger (Freiburg, Germany). Rp-adenosine-3',5'-monophosphothioate (Rp-cAMPS) was purchased from BioLog (Bremen, Germany). $\mathrm{N}$-[2( $p$-bromocinnamyl-amino)ethyl]-5-isoquinolinesulfonamide $\mathrm{HCl}(\mathrm{H}$ 89) was purchased from Calbiochem-Novabiochem (San Diego, CA). cAMP [ $\left.{ }^{125} \mathrm{I}\right]$ assay system was purchased from Amersham International (Little Chalfont, United Kingdom).

Isolation of rat hepatocyte couplets. Male Wistar rats (F. Morini, Reggio Emilia, Italy), weighing 240-260 grams, were housed in temperature- and light-controlled rooms and allowed free access to water and laboratory chow. Animals received humane care and the study protocol was in compliance with our institution's ethical guidelines.

IRHC were prepared by a modification (21) of Seglen's procedure (22). The animals were anesthetized with pentobarbital $(50 \mathrm{mg} / \mathrm{kg}$ intraperitoneally). The portal vein was cannulated by a 16-gauge cannula, and the liver was perfused in situ for $7 \mathrm{~min}$ with $\mathrm{Ca}^{2+}, \mathrm{Mg}^{2+}$-free Hanks' medium ( $\mathrm{NaCl} 120 \mathrm{mM}, \mathrm{KCl} 5.0 \mathrm{mM}, \mathrm{NaHCO}_{3} 25 \mathrm{mM}, \mathrm{KH}_{2} \mathrm{PO}_{4} 0.66$ $\mathrm{mM}, \mathrm{Na}_{2} \mathrm{HPO}_{4} 0.33 \mathrm{mM}, 0.1 \%$ D-glucose) and then with $\mathrm{Ca}^{2+}, \mathrm{Mg}^{2+}$ containing Hanks' buffer supplemented with $0.05 \%$ collagenase A plus $0.8 \mathrm{U}$ trypsin inhibitor/U of collagenase tryptic activity. When the capsula began to detach, the liver was removed from the carcass, grasped at the hilum by forceps, and the hepatocytes were combed into L-15 medium at $0^{\circ} \mathrm{C}$. Cell suspension was then sequentially filtered through 80 - and $45-\mu \mathrm{m}$ mesh nylon monofilament screens and centrifuged at $50 \mathrm{~g}$. Supernatant was discarded, and the cells were washed three times with cold L-15 medium. Cell suspension was plated on small cover slip fragments $(5 \times 5 \mathrm{~mm}$ ), layered on culture plastic wells (Corning Inc., Corning, $\mathrm{NY}$ ) incubated at $37^{\circ} \mathrm{C}$ in an air-equilibrated incubator. In experiments performed in the absence of $\mathrm{HCO}_{3}^{-}$, cells were plated in L-15 medium containing penicillin/streptomycin $(100,000 \mathrm{U} / 100 \mu \mathrm{g} /$ liter $)$, L-glutamine $(2 \mathrm{mM})$, FCS $(10 \%)$, and insulin $(0.1 \mu \mathrm{M})$. In experiments performed in KRB, cells were plated in $\alpha$-MEM medium containing the same additive as L-15, but $25 \mathrm{mM} \mathrm{NaHCO}_{3}^{-}$was used to replace $25 \mathrm{mM}$ Hepes. Medium was changed after $2 \mathrm{~h}$ and experiments were performed between 2 and $6 \mathrm{~h}$ after plating.

The yield of our preparation was $1-1.9 \times 10^{7}$ hepatocytes per gram of liver, with a viability (Trypan blue exclusion) ranging from 75 to $88 \%(n=73$ cell preparations $)$. Couplets represent $20 \pm 5 \%$ of the cell preparation, with a viability constantly $>90 \%$. Cell viability was not significantly decreased by preincubation with $\mathrm{Cl}^{-}$-free solutions, DIDS $(0.5 \mathrm{mM})$, amiloride ( $1 \mathrm{mM})$, NPPB $(10 \mu \mathrm{M})$, colchicine or $\beta$-lumicolchicine $\left(10^{-5} \mathrm{M}\right)$, Rp-cAMPS $(10 \mu \mathrm{M})$, or H-89 $(30 \mu \mathrm{M})$.

$\mathrm{pH}_{\mathrm{i}}$ determination. $\mathrm{pH}_{\mathrm{i}}$ of IRHC was measured using a microfluorimetric single-cell method (SPEX-AR-CM-micro system; Spex Industries, Edison, $\mathrm{NJ})$ and $\mathrm{BCECF}-\mathrm{AM}$ as a fluorescent $\mathrm{pH}_{\mathrm{i}}$ indicator (18, $23,24)$. Cells on glass coverslips were loaded with BCECF-AM (12 $\mu \mathrm{m}$ ) for $10 \mathrm{~min}$, washed for $10 \mathrm{~min}$ in a BCECF-free medium, and transferred into a thermostated perfusion chamber placed on the stage of a Nikon Diaphot inverted microscope. The perfusion media were constantly warmed at $37^{\circ} \mathrm{C}$ and gassed both by direct bubbling and by an artificial lung. For the experiments performed in $\mathrm{HCO}_{3}^{-}$-enriched media, gas-impermeable tubing was used. Coverslips were scanned under DIC optics and an isolated couplet with a well developed canalicular pole was selected. Couplets with membrane blebs were avoided. Signal recording was obtained from one of the two hepatocytes constituting the couplet by using a pin hole device (Nikon) inserted in the emission light pathway. The microscope was connected with a rotating chopper mirror able to rapidly alternate the light generated by a $150 \mathrm{~W}$ xenon lamp between two excitation beams (490 and $440 \mathrm{~nm}$ ). Light was attenuated to $0.1 \%$ by heat reflectors and neutral density filters (Omega Optics, Eugene, OR). The emitted light was read at $530 \mathrm{~nm}$, integrated by the computer with 500 -ms acquisitions every $1,500 \mathrm{~ms}$ and displayed in real time. All measurements for each excitation wavelength were corrected for background fluorescence obtained from dye-free cells. Fluorescence intensity exceeded background autofluorescence by at least 30 -fold. The 490/440 fluorescence intensity ratio data were converted to $\mathrm{pH}_{\mathrm{i}}$ values by using the nigericin $(12 \mu \mathrm{m})$ calibration curve technique $(6-8,18,23-25)$. Over the $\mathrm{pH}$ range of 6.4-7.7, fluorescence varied in a linear fashion with $\mathrm{pH}_{\text {out }}$.

Total and intrinsic intracellular buffering power. The intrinsic buffering power $\left(\beta_{\mathrm{i}}\right)$ was determined at different $\mathrm{pH}_{\mathrm{i}}$ as described $(7,18$, $24,26-30$ ), by exposing the cells to $25 \mathrm{mM} \mathrm{NH}_{4} \mathrm{Cl}$ in Hepes, $\mathrm{Na}^{+}$free buffered solutions and then decreasing the $\mathrm{NH}_{4} \mathrm{Cl}$ concentration by 5 or $10 \mathrm{mM}$ for each step to $0 \mathrm{mM}(n=10)$. The $\beta_{\mathrm{i}}$ was then calculated from the midpoint change in $\mathrm{pH}_{\mathrm{i}}$ at each step. $\beta_{\mathrm{i}}$ values were then plotted versus $\mathrm{pH}_{\mathrm{i}}$ using a best-fit program (Enzfitter). $\beta_{\mathrm{i}} / \mathrm{pH}_{\mathrm{i}}$ curves were also evaluated in IRHC perfused with $200 \mathrm{nM}$ glucagon $(n=8)$. As in other studies $(7,18,24)$ a single exponential function provides a better description of the known $\beta_{\mathrm{i}} / \mathrm{pH}_{\mathrm{i}}$ relationships. $\beta_{\mathrm{i}}$ changed from $10.4 \mathrm{mM} / \mathrm{pH} \mathrm{U}$ at $\mathrm{pH}_{\mathrm{i}} 7.5$ to $25 \mathrm{mM} / \mathrm{pH} \mathrm{U}$ at $\mathrm{pH}_{\mathrm{i}} 7$ and to $66 \mathrm{mM} /$ $\mathrm{pH} \mathrm{U}$ at $\mathrm{pH}_{\mathrm{i}} 6.5$ and was not significantly influenced by glucagon at each $\mathrm{pH}_{\mathrm{i}}$ value. We found values of $\beta_{\mathrm{i}}$ in IRHC which were very close to those measured in subconfluent monolayer of rat hepatocytes (7). For each experimental protocol, $\beta_{\mathrm{i}}$ was obtained from the relative $\beta_{\mathrm{i}} /$ $\mathrm{pH}_{\mathrm{i}}$ curves as estimated above, for that $\mathrm{pH}_{\mathrm{i}}$ at which $\delta \mathrm{pH}_{\mathrm{i}} / \delta \mathrm{t}$ was measured. $\mathrm{H}^{+}$fluxes were then calculated by the formula: $\mathrm{H}^{+}$fluxes $=\beta_{\mathrm{i}}$ $\times \delta \mathrm{pH}_{\mathrm{i}} / \mathrm{min}$. In this formula, $\beta_{\mathrm{tot}}$ substituted for $\beta_{\mathrm{i}}$ when experiments were performed in the presence of bicarbonate. $\beta_{\text {tot }}$ was calculated from the formula $\beta_{\text {tot }}=\beta_{\mathrm{i}}+2.303 \times\left[\mathrm{HCO}_{3}^{-}\right]_{\mathrm{i}}$ where intracellular $\left[\mathrm{HCO}_{3}^{-}\right]$is derived from the Henderson-Hasselbach equation.

cAMP levels in isolated rat hepatocytes. CAMP was measured in isolated rat hepatocytes cultured in $\alpha$-MEM and incubated with glucagon, agonists, or inhibitors under the same conditions as those for $\mathrm{pH}_{\mathrm{i}}$ measurement in IRHC. cAMP was extracted from cells and measured by using a kit (Amersham International) composed by Amprep ${ }^{\mathrm{TM}} \mathrm{SAX}$ minicolumn and cAMP $\left[{ }^{125} \mathrm{I}\right]$ assay system and by following instructions included in the kit.

Solutions. The compositions of solutions used in the study have been previously detailed $(7,8,18,24)$. Glucagon, made up as a concentrated solution in the appropriate perifusion buffer containing $1 \%(\mathrm{wt} / \mathrm{vol})$ bovine serum albumin, was infused (1:50 vol/vol dilution) into the perifusion fluid, at a rate calculated to produce the required final concentration. NPPB, forskolin, and PMA were dissolved in DMSO and then diluted $(1: 1,000, \mathrm{vol} / \mathrm{vol})$ in the perifusion solution to the required final concentration.

Statistical analysis. Data are presented as arithmetic means \pm standard deviations. Statistical analysis was conducted using the paired or unpaired Student's $t$ test as appropriate or ANOVA when three groups were compared.

\section{Results}

Experiments in bicarbonate-free media. In nominally bicarbonate-free, Hepes-buffered media, IRHC maintained a basal $\mathrm{pH}_{\mathrm{i}}$ 
Table I. Recovery from an Acute Acid Load in the Presence (KRB) or Absence (Hepes) of Bicarbonate

\begin{tabular}{|c|c|c|c|c|}
\hline Condition & Basal $\mathrm{pH}_{\mathrm{i}}$ & Nadir $\mathbf{p H}_{\mathbf{i}}$ & Recovery rates & $\mathrm{JH}^{+}$ \\
\hline & & & pH U/min & $m M / \min$ \\
\hline \multicolumn{5}{|l|}{ Hepes } \\
\hline Controls $(n=7)$ & $7.09 \pm 0.07$ & $6.70 \pm 0.09$ & $0.145 \pm 0.042$ & $6.35 \pm 2.50$ \\
\hline Glucagon & $7.11 \pm 0.08$ & $6.71 \pm 0.15$ & $0.130 \pm 0.020$ & $5.58 \pm 1.89$ \\
\hline \multicolumn{5}{|l|}{ KRB + amiloride } \\
\hline Controls $(n=8)$ & $7.18 \pm 0.10$ & $6.69 \pm 0.07$ & $0.172 \pm 0.032$ & $9.63 \pm 3.20$ \\
\hline Glucagon & $7.15 \pm 0.07$ & $6.70 \pm 0.08$ & $0.165 \pm 0.042$ & $8.94 \pm 3.72$ \\
\hline \multicolumn{5}{|c|}{$\mathrm{KRB}, \mathrm{Cl}^{-}$depletion + amiloride } \\
\hline Controls $(n=8)$ & $7.40 \pm 0.07$ & $7.12 \pm 0.02$ & $0.063 \pm 0.016$ & $3.28 \pm 0.82$ \\
\hline Glucagon & $7.43 \pm 0.06$ & $7.13 \pm 0.02$ & $0.086 \pm 0.018^{*}$ & $4.49 \pm 1.20 *$ \\
\hline
\end{tabular}

Hepes, IRHC perfused with nominally bicarbonate-free Hepes-buffered media were submitted to a $20 \mathrm{mM} \mathrm{NH}_{4} \mathrm{Cl}$ acid load. The recovery rate from this acid load is a measure of the $\mathrm{Na}^{+} / \mathrm{H}^{+}$exchanger activity. When two consecutive $\mathrm{NH}_{4} \mathrm{Cl}$ pulses were performed in the same cell, the second during superfusion with $200 \mathrm{nM}$ glucagon, no difference in the recovery rates were found. KRB + amiloride, IRHC perfused with KRB were submitted to two consecutive $20 \mathrm{mM} \mathrm{NH}_{4} \mathrm{Cl}$ acid loads. At the moment of $\mathrm{NH}_{4} \mathrm{Cl}$ withdrawal, $1 \mathrm{mM}$ amiloride was administered to exclude the $\mathrm{Na}^{+} / \mathrm{H}^{+}$exchanger. The recovery from the $\mathrm{NH}_{4} \mathrm{Cl}$-amiloride acid pulse is a measure of the $\mathrm{Na}^{+}-\mathrm{HCO}_{3}^{-}$symport activity. When two consecutive $\mathrm{NH}_{4} \mathrm{Cl}$-amiloride pulses were performed in the same cell, the second in the presence of $200 \mathrm{nM}$ glucagon, no difference in the recovery rates was found. $\mathrm{KRB}, \mathrm{Cl}^{-}$depletion + amiloride, to measure the activity of the $\mathrm{Na}^{+}-\mathrm{HCO}_{3}^{-}$symport at $\mathrm{pH}_{\mathrm{i}}$ values close to basal $\mathrm{pH}_{\mathrm{i}}$ of $\mathrm{IRHC}$, we used a protocol where $\mathrm{Cl}^{-}$-depleted IRHC were submitted to a $15 \mathrm{mM} \mathrm{NH}_{4}$-amiloride acid load. In these experimental conditions nadir acidification was 7.12 \pm 0.02 . Glucagon administered in correspondence of a second $\mathrm{NH}_{4}$-amiloride acid load significantly increased the recovery rate with respect to the basal values (first control $\mathrm{NH}_{4}$-amiloride acid load). Findings indicate that glucagon stimulates the $\mathrm{Na}^{+}-\mathrm{HCO}_{3}^{-}$symport at $\mathrm{pH}$ the basal $\mathrm{pH}_{\mathrm{i}}$ of $\mathrm{IRHC}$ but not at acid $\mathrm{pH}_{\mathrm{i}}$ values. Data are means \pm SD. ${ }^{*} P<0.03$ vs. control values.

of $7.09 \pm 0.05(n=13)$. Basal $\mathrm{pH}_{\mathrm{i}}$ was unmodified by $10 \mathrm{~min}$ of exposure to $200 \mathrm{nM}$ glucagon $(n=13)$. In the absence of bicarbonate, $\mathrm{pH}_{\mathrm{i}}$ regulation in hepatocytes was mediated by the activity of the $\mathrm{Na}^{+} / \mathrm{H}^{+}$exchanger $(6,23)$. The lack of a glucagon effect on basal $\mathrm{pH}_{\mathrm{i}}$, in bicarbonate-free media, suggests that this hormone does not influence the activity of the $\mathrm{Na}^{+} /$ $\mathrm{H}^{+}$exchanger. However, we directly evaluated whether glucagon may influence the activity of this exchanger, assessed by the effect of amiloride on basal $\mathrm{pH}_{\mathrm{i}}$ and the recovery from acid load. Amiloride ( $1 \mathrm{mM})$, a specific inhibitor of the $\mathrm{Na}^{+} / \mathrm{H}^{+}$ exchange, promoted a $0.14 \pm 0.04 \mathrm{pH} \mathrm{U}$ acidification, the cell recovering to the basal $\mathrm{pH}_{\mathrm{i}}$ after amiloride withdrawal. When amiloride exposure/withdrawal was repeated in the same cell but during superfusion with $200 \mathrm{nM}$ glucagon, the same acidification was found $(-0.15 \pm 0.04 \mathrm{pH} \mathrm{U} ; n=6)$. The activity of the $\mathrm{Na}^{+} / \mathrm{H}^{+}$exchanger was then measured by evaluating the rate of $\mathrm{pH}_{\mathrm{i}}$ recovery from an acute acid load $\left(20 \mathrm{mM} \mathrm{NH}_{4} \mathrm{Cl}^{-}\right)$ in Hepes. The recovery from this acid load is driven by the activity of the $\mathrm{Na}^{+} / \mathrm{H}^{+}$exchanger $(6,23)$. When two consecutive $\mathrm{NH}_{4} \mathrm{Cl}^{-}$pulses were applied, no significant difference in the maximal rate (at nadir $\mathrm{pH}_{\mathrm{i}}$ ) of $\mathrm{pH}_{\mathrm{i}}$ recovery was found ( $n$ $=7$ ). To evaluate the effect of glucagon, when the recovery from the first pulse was completed, the cell was superfused with $200 \mathrm{nM}$ glucagon, and after 4-6 min a second $\mathrm{NH}_{4} \mathrm{Cl}^{-}$pulse was performed. The rate of recovery at nadir $\mathrm{pH}_{\mathrm{i}}$ was compared with those measured after the first control pulse. During glucagon exposure, both the degree of acidification after $\mathrm{NH}_{4} \mathrm{Cl}^{-}$ withdrawal (nadir $\mathrm{pH}_{\mathrm{i}}=6.71 \pm 0.15$ ) and the maximal rate of recovery $\left(0.130 \pm 0.020 \mathrm{pH} \mathrm{U} / \mathrm{min} ; \mathrm{JH}^{+}=5.58 \pm 1.89 \mathrm{mM} /\right.$ min) were similar to control values $(n=7$; Table I). These findings further confirm that glucagon has no effect on the activity of the $\mathrm{Na}^{+} / \mathrm{H}^{+}$exchanger, evaluated at either basal $\mathrm{pH}_{\mathrm{i}}$ (amiloride effect on basal $\mathrm{pH}_{\mathrm{i}}$ ) or at acid $\mathrm{pH}_{\mathrm{i}}$ values (recovery from an acute acid load).

Experiments in bicarbonate-containing media. The basal $\mathrm{pH}_{\mathrm{i}}$ of IRHC cultured and perfused with media supplemented with
$25 \mathrm{mM} \mathrm{HCO}_{3}^{-}(7.20 \pm 0.07, n=72)$, was higher $(P<0.001)$ than in the nominal absence of $\mathrm{HCO}_{3}^{-}$, indicating that a $\mathrm{HCO}_{3}^{-}$ loading mechanism is active. Exposure for $10 \mathrm{~min}$ to $200 \mathrm{nM}$ glucagon $(n=10), 500 \mathrm{nM}$ glucagon $(n=5), 200 \mathrm{nM}$ glucagon $+100 \mu \mathrm{M}$ IBMX $(n=5)$ showed no detectable changes in basal $\mathrm{pH}_{\mathrm{i}}$. Basal $\mathrm{pH}_{\mathrm{i}}$ also remained unchanged when glucagon was administered in cells perifused in $\mathrm{HCO}_{3}^{-}$-containing media, with amiloride to inhibit the $\mathrm{Na}^{+} / \mathrm{H}^{+}$exchanger $(n=6)$, thus excluding the involvement of this acid extruder as a mechanism of $\mathrm{pH}_{\mathrm{i}}$ maintenance during glucagon exposure.

Effect of glucagon and DBcAMP + forskolin on $\mathrm{Cl}^{-}$/ $\mathrm{HCO}_{3}^{-}$exchange (Table II, Fig. 1). The activity of the $\mathrm{Cl}^{-}$/ $\mathrm{HCO}_{3}^{-}$exchanger was measured in IRHC, cultured and perfused with $\mathrm{HCO}_{3}^{-}$-enriched media, by using the method of acute external $\mathrm{Cl}^{-}$removal/readmission (7, 8, 18, 24, 27-30). Acute $\mathrm{Cl}^{-}$ removal (equimolar substitution with gluconate) produces an intracellular alkalinization due to the exit of internal $\mathrm{Cl}^{-}$in exchange with external $\mathrm{HCO}_{3}^{-}, \mathrm{pH}_{\mathrm{i}}$ recovering to baseline when external $\mathrm{Cl}^{-}$is readmitted to drive the exchanger in the opposite direction. The net $\mathrm{pH}_{\mathrm{i}}$ increase promoted by $\mathrm{Cl}^{-}$removal $\left(\delta \mathrm{pH}_{\mathrm{i}}\right)$ and the rate of both $\mathrm{pH}_{\mathrm{i}}$ increase after $\mathrm{Cl}^{-}$removal and $\mathrm{pH}_{\mathrm{i}}$ recovery after $\mathrm{Cl}^{-}$readmission were the parameters measured to evaluate the activity of the $\mathrm{Cl}^{-} / \mathrm{HCO}_{3}^{-}$exchanger. The effect of $\mathrm{Cl}^{-}$removal was completely abolished by $0.5 \mathrm{mM}$ DIDS pretreatment (40-60 min of preincubation; $n=6$ ) indicating that the increase in $\mathrm{pH}_{\mathrm{i}}$ induced by acute $\mathrm{Cl}^{-}$removal depends on the transport of $\mathrm{HCO}_{3}^{-}$across the cell membrane. When two consecutive $\mathrm{Cl}^{-}$removal/readmission maneuvers were performed no significant difference was found in the three measured parameters $(n=10)$. To evaluate the effect of glucagon, a second $\mathrm{Cl}^{-}$removal/readmission maneuver was performed during superfusion with the hormone $(200 \mathrm{nM} ; n=10)$ and findings compared with those obtained after the first (control) maneuver. During glucagon perfusion, the net $\mathrm{pH}_{\mathrm{i}}$ increase $(0.28 \pm 0.04 \mathrm{pH} \mathrm{U})$ and the maximal rate of alkalinization $\left(0.145 \pm 0.025 \mathrm{pH} \mathrm{U} / \mathrm{min} ; \mathrm{H}^{+}\right.$flux $\left.=7.78 \pm 1.58 \mathrm{mM} / \mathrm{min}\right)$ in - 
Table II. Effect of Glucagon and DBcAMP + Forskolin on Chloride/Bicarbonate Exchange Activity

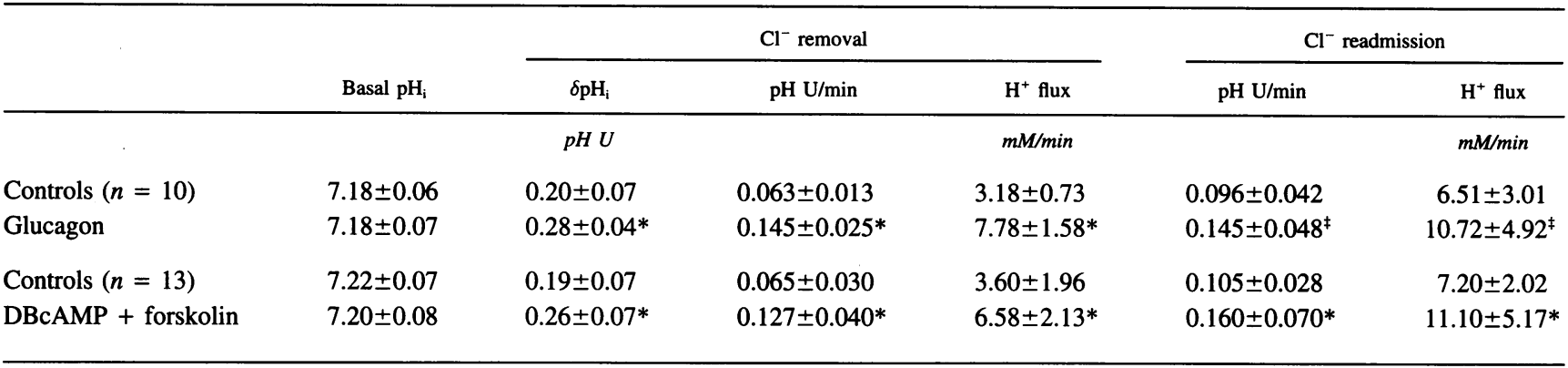

Two consecutive $\mathrm{Cl}^{-}$removal/readmission maneuvers were performed, the second during superfusion with glucagon $(200 \mathrm{nM}, n=10)$ or DBcAMP $(100 \mu \mathrm{M})+$ forskolin $(10 \mu \mathrm{M})(n=13)$. The net $\mathrm{pH}_{\mathrm{i}}$ increase $\left(\delta \mathrm{pH}_{\mathrm{i}}\right)$ and the maximal rate of $\mathrm{pH}_{\mathrm{i}}$ increase after acute $\mathrm{Cl}^{-}$removal as well as the maximal rate of $\mathrm{pH}_{\mathrm{i}}$ recovery after $\mathrm{Cl}^{-}$readmission were compared between the first (control) and the second (glucagon or DBcAMP + forskolin) acute $\mathrm{Cl}^{-}$removal/readmission maneuver. Data are means \pm SD. ${ }^{*} P<0.02$ vs. control values. ${ }^{\ddagger} P<0.05$ vs. control values.

duced by $\mathrm{Cl}^{-}$removal were significantly $(P<0.02)$ higher then control values (Table II, Fig. 1). Glucagon also increased $(P<0.05)$ the rate of $\mathrm{pH}_{\mathrm{i}}$ recovery after $\mathrm{Cl}^{-}$readmission (Table II, Fig. 1). This demonstrates that glucagon stimulates the activity of the $\mathrm{Cl}^{-} / \mathrm{HCO}_{3}^{-}$exchanger.

To assess whether glucagon stimulation of the $\mathrm{Cl}^{-} / \mathrm{HCO}_{3}^{-}$ exchange could be mediated by CAMP (31), we tried to reproduce the effect of the hormone by using a mixture composed
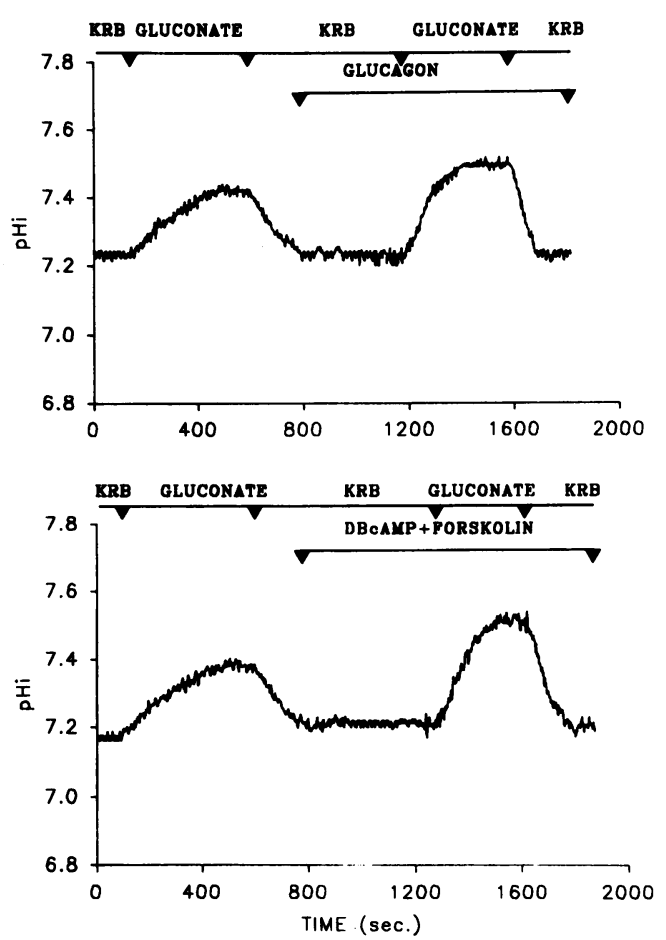

Figure 1. Effect of glucagon or DBcAMP + forskolin on $\mathrm{pH}_{\mathrm{i}}$ changes promoted by acute chloride removal and readmission. IRHC were perfused with bicarbonate containing solutions (KRB). Two consecutive $\mathrm{Cl}^{-}$removal/readmission (equimolar substitution with gluconate) maneuvers were then performed, the second during superfusion with $200 \mathrm{nM}$ glucagon (upper tracing, $n=10)$, or DBcAMP $(100 \mu \mathrm{M})$ + forskolin $(10 \mu \mathrm{M})$ (lower tracing, $n=13)$. The net $\mathrm{pH}_{\mathrm{i}}$ increase $\left(\delta \mathrm{pH}_{\mathrm{i}}\right)$ and the maximal rate of $\mathrm{pH}_{\mathrm{i}}$ increase after acute $\mathrm{Cl}^{-}$removal as well as the maximal rate of $\mathrm{pH}_{\mathrm{i}}$ recovery after $\mathrm{Cl}^{-}$readmission were significantly higher during exposure to glucagon or DBcAMP + forskolin with respect to control values (first acute $\mathrm{Cl}^{-}$removal/readmission maneuver). of a membrane permeant cAMP analogue (DBcAMP, $100 \mu \mathrm{M}$ ) and a stimulator of adenyl cyclase (forskolin, $10 \mu \mathrm{M}$ ). During superfusion with DBcAMP + forskolin, the net $\mathrm{pH}_{\mathrm{i}}$ increase $(0.26 \pm 0.07 \mathrm{pH} \mathrm{U})$ and the maximal rate of alkalinization $\left(0.127 \pm 0.040 \mathrm{pH} \mathrm{U} / \mathrm{min} ; \mathrm{H}^{+}\right.$flux $\left.=6.58 \pm 2.13 \mathrm{mM} / \mathrm{min}\right)$ after $\mathrm{Cl}^{-}$removal and the rate of $\mathrm{pH}_{\mathrm{i}}$ recovery after $\mathrm{Cl}^{-}$readmission $\left(0.160 \pm 0.070 \mathrm{pH} \mathrm{U} / \mathrm{min} ; \mathrm{H}^{+}\right.$flux $\left.=11.10 \pm 5.17 \mathrm{mM} / \mathrm{min}\right)$ were higher $(P<0.02)$ than corresponding control values (first maneuver, Table II, Fig. $1 ; n=13$ ). This indicates that the $\mathrm{Cl}^{-} /$ $\mathrm{HCO}_{3}^{-}$exchanger is stimulated in conditions capable of increasing intracellular cAMP.

Effect of protein kinase A inhibitors (Rp-cAMPS, $H-89)$ on glucagon stimulation of the $\mathrm{Cl}^{-} / \mathrm{HCO}_{3}^{-}$exchanger activity ( $\mathrm{Ta}$ ble III, Fig. 2). Cells were preincubated ( $30 \mathrm{~min}$ ) and perfused with $10 \mu \mathrm{M}$ Rp-cAMPS $(n=10)$ or with $30 \mu \mathrm{M} \mathrm{H}-89$ ( $n$ $=10$ ). Two consecutive $\mathrm{Cl}^{-}$removal/readmission maneuvers were then performed, the second during superfusion with 200 $\mathrm{nM}$ glucagon. The effect of protein kinase $\mathrm{A}$ inhibitors on the basal (first $\mathrm{Cl}^{-}$removal/readmission maneuver) and on the glucagon-stimulated (second maneuver) $\mathrm{Cl}^{-} / \mathrm{HCO}_{3}^{-}$exchange activity was evaluated in comparison (ANOVA) with control experiments performed in the absence of inhibitors, but with glucagon superfusion during the second $\mathrm{Cl}^{-}$removal/readmission maneuver (Table III, Fig. 2).

IRHC pretreated and perfused with Rp-cAMPS or with $\mathrm{H}$ 89 showed a basal activity of the $\mathrm{Cl}^{-} / \mathrm{HCO}_{3}^{-}$exchanger (first $\mathrm{Cl}^{-}$removal/readmission maneuver) similar to controls ( $n$ $=12$ ). In fact, the net $\mathrm{pH}_{\mathrm{i}}$ increase and the rate of alkalinization after $\mathrm{Cl}^{-}$removal as well as the rate of $\mathrm{pH}_{\mathrm{i}}$ recovery after $\mathrm{Cl}^{-}$ readmission were unchanged either by Rp-cAMPS or by H-89. In contrast, both Rp-cAMPS and H-89 significantly inhibited the glucagon-stimulated $\mathrm{Cl}^{-} / \mathrm{HCO}_{3}^{-}$exchange activity. In fact, when glucagon was administered ( second $\mathrm{Cl}^{-}$removal/readmission maneuver), the net $\mathrm{pH}_{\mathrm{i}}$ increase and the rate of alkalinization after $\mathrm{Cl}^{-}$removal as well as the rate of $\mathrm{pH}_{\mathrm{i}}$ recovery after $\mathrm{Cl}^{-}$readmission were significantly lower in IRHC pretreated and perfused with Rp-cAMPS $(P<0.03)$ or with $\mathrm{H}$ $89(P<0.02)$ in comparison with the corresponding parameters measured in control IRHC. Glucagon increased by $106 \%$ the basal rate of alkalinization induced by $\mathrm{Cl}^{-}$removal $(P<0.01)$ and by $66 \%$ the basal rate of $\mathrm{pH}_{\mathrm{i}}$ recovery after $\mathrm{Cl}^{-}$readmission $(P<0.02)$ in control IRHC. In contrast, glucagon increased the basal rate of alkalinization induced by $\mathrm{Cl}^{-}$removal by only $36 \%(P<0.05)$ in Rp-cAMPS-treated IRHC while no significant increase was found in $\mathrm{H}-89$-treated cells. The rate of $\mathrm{pH}_{\mathrm{i}}$ recovery after $\mathrm{Cl}^{-}$readmission was unchanged by glucagon in either Rp-cAMPS - or H-89-treated cells. 
Table III. Effect of Protein Kinase A Inhibitors (Rp-cAMPS, H-89) on the Basal and Glucagon-stimulated Chloride/Bicarbonate Exchange Activity

\begin{tabular}{|c|c|c|c|c|c|c|}
\hline & \multirow[b]{2}{*}{ Basal $\mathrm{pH}_{\mathrm{i}}$} & \multicolumn{3}{|c|}{$\mathrm{Cl}^{-}$removal } & \multicolumn{2}{|c|}{$\mathrm{Cl}^{-}$readmission } \\
\hline & & $\delta \mathrm{pH}_{\mathrm{i}}$ & $\mathrm{pH} \mathrm{U/min}$ & $\mathrm{H}^{+}$flux & $\mathrm{pH} \mathrm{U} / \min$ & $\mathrm{H}^{+}$flux \\
\hline & & $p H U$ & & $\mathrm{mM} / \mathrm{min}$ & & $m M / \min$ \\
\hline Controls $(n=12)$ & $7.22 \pm 0.06$ & $0.19 \pm 0.07$ & $0.067 \pm 0.034$ & $3.68 \pm 1.85$ & $0.091 \pm 0.043$ & $6.36 \pm 3.34$ \\
\hline Glucagon & $7.21 \pm 0.05$ & $0.26 \pm 0.05 *$ & $0.138 \pm 0.045^{* \ddagger}$ & $7.49 \pm 2.44^{* \pm}$ & $0.151 \pm 0.046^{* \ddagger}$ & $10.83 \pm 3.39^{* \neq}$ \\
\hline Rp-cAMPS $(n=10)$ & $7.21 \pm 0.10$ & $0.22 \pm 0.06$ & $0.069 \pm 0.018$ & $3.85 \pm 0.93$ & $0.100 \pm 0.024$ & $7.57 \pm 2.11$ \\
\hline Rp-cAMPS + glucagon & $7.22 \pm 0.06$ & $0.24 \pm 0.04$ & $0.094 \pm 0.031^{8}$ & $5.20 \pm 1.62^{8}$ & $0.105 \pm 0.034$ & $7.62 \pm 2.00$ \\
\hline H-89 $(n=10)$ & $7.22 \pm 0.06$ & $0.20 \pm 0.04$ & $0.073 \pm 0.024$ & $4.05 \pm 1.30$ & $0.094 \pm 0.031$ & $6.63 \pm 2.55$ \\
\hline H-89 + glucagon & $7.20 \pm 0.10$ & $0.23 \pm 0.06$ & $0.080 \pm 0.025$ & $4.39 \pm 1.36$ & $0.109 \pm 0.037$ & $7.42 \pm 2.73$ \\
\hline
\end{tabular}

Two consecutive $\mathrm{Cl}^{-}$removal/readmission maneuvers were performed, the second during superfusion with $200 \mathrm{nM}$ glucagon, in IRHC pretreated (30 $\mathrm{min})$ and perfused with $10 \mu \mathrm{M}$ Rp-cAMPS $(n=10)$ or with $30 \mu \mathrm{M} \mathrm{H}-89(n=10)$. Data were compared (ANOVA) with respect to control untreated IRHC $(n=12)$. The net $\mathrm{pH}_{\mathrm{i}}$ increase $\left(\mathrm{ppH}_{\mathrm{i}}\right)$ and the maximal rate of $\mathrm{pH}_{\mathrm{i}}$ increase after acute $\mathrm{Cl}^{-}$removal as well as the maximal rate of $\mathrm{pH}_{\mathrm{i}}$ recovery after $\mathrm{Cl}^{-}$readmission measured during the first maneuver (basal activity of the $\mathrm{Cl}^{-} / \mathrm{HCO}_{3}^{-}$exchanger) were not influenced by $\mathrm{Rp}$ cAMPS nor by H-89. The same parameters measured in the presence of glucagon (second maneuver) were significantly higher in untreated IRHC with respect to IRHC treated with Rp-cAMPS or with H-89. Data are means \pm SD. ${ }^{*} P<0.02$ vs. control basal values. ${ }^{\ddagger} P<0.03$ vs. Rp-cAMPS + glucagon or $\mathrm{H}-89+$ glucagon. ${ }^{8} P<0.05$ vs. Rp-cAMPS alone.

When two consecutive $\mathrm{Cl}^{-}$removal/readmission maneuvers were performed in IRHC pretreated and perfused with RpcAMPS $(n=6)$ or with $\mathrm{H}-89(n=6)$ but without glucagon administration, no significant differences were found in the three measured parameters between the first and the second maneuver.

Effect of the $\mathrm{Cl}^{-}$channel blocker, NPPB, on the glucagon stimulation of the $\mathrm{Cl}^{-} / \mathrm{HCO}_{3}^{-}$exchanger activity (Table $\mathrm{IV}$, Fig. 3). Since the activity of $\mathrm{Cl}^{-} / \mathrm{HCO}_{3}^{-}$exchangers may be regulated either by a direct effect of second messengers on the transporter or, indirectly, by modifying the rate of $\mathrm{Cl}^{-}$flux across $\mathrm{Cl}^{-}$channels in the cell membrane as described in other epithelia $(11-15,19,32,33)$, the effect of NPPB, a specific and potent $\mathrm{Cl}^{-}$channel blocker (34), on the glucagon response in IRHC was assessed. NPPB alone showed no effect on the activity of the $\mathrm{Cl}^{-} / \mathrm{HCO}_{3}^{-}$exchange. In fact, when two consecutive $\mathrm{Cl}^{-}$removal/readmission maneuvers were performed, the second in the presence of $10 \mu \mathrm{M}$ NPPB, no differences in the $\mathrm{pH}_{\mathrm{i}}$ changes induced by $\mathrm{Cl}^{-}$removal/readmission were found ( $n=7$, Table IV). To evaluate the effect of NPPB on the glucagon stimulation of the $\mathrm{Cl}^{-} / \mathrm{HCO}_{3}^{-}$exchange, after the first control maneuver, cells were superfused with $10 \mu \mathrm{M}$ NPPB and 2 min later with NPPB + glucagon ( $n=7$; Table IV, Fig. 3 ). Even in the presence of NPPB, glucagon stimulates $(P<0.02)$ the net $\mathrm{pH}_{\mathrm{i}}$ increase after $\mathrm{Cl}^{-}$removal $(0.27 \pm 0.05 \mathrm{pH} \mathrm{U})$, the rate of alkalinization after $\mathrm{Cl}^{-}$removal $(0.157 \pm 0.052 \mathrm{pH} \mathrm{U} /$ $\min ; \mathrm{H}^{+}$flux $=9.34 \pm 3.16 \mathrm{mM} / \mathrm{min}$ ) and the rate of $\mathrm{pH}_{\mathrm{i}}$ recovery after $\mathrm{Cl}^{-}$readmission $\left(0.197 \pm 0.089 \mathrm{pH} \mathrm{U} / \mathrm{min} ; \mathrm{H}^{+}\right.$flux $=13.40 \pm 6.59 \mathrm{mM} / \mathrm{min}$ ) with respect to the control values (first maneuver; Table IV, Fig. 3). These findings indicate that NPPB does not influence the glucagon stimulation of the $\mathrm{Cl}^{-}$/ $\mathrm{HCO}_{3}^{-}$exchanger, suggesting that the hormonal effect is not mediated by NPPB-sensitive $\mathrm{Cl}^{-}$channels.

Effect of PMA on the glucagon stimulation of $\mathrm{Cl}^{-} / \mathrm{HCO}_{3}^{-}$ exchanger (Table IV, Fig. 3). To evaluate the role of protein kinase $\mathrm{C}$ on the basal and glucagon-stimulated $\mathrm{Cl}^{-} / \mathrm{HCO}_{3}^{-}$exchange, we investigated the effect of the agonist PMA on the $\mathrm{pH}_{\mathrm{i}}$ changes promoted by $\mathrm{Cl}^{-}$removal/readmission in the ab- sence of or during glucagon exposure. PMA alone showed no effect on the activity of the $\mathrm{Cl}^{-} / \mathrm{HCO}_{3}^{-}$exchanger. In fact, when two consecutive $\mathrm{Cl}^{-}$removal/readmission maneuvers were performed, the second in the presence of $10 \mu \mathrm{M}$ PMA, no significant differences in the $\mathrm{pH}_{\mathrm{i}}$ changes induced by $\mathrm{Cl}^{-}$ removal/readmission were found ( $n=7$, Table IV). To evaluate the effect of PMA on the glucagon stimulation of the $\mathrm{Cl}^{-}$/ $\mathrm{HCO}_{3}^{-}$exchange, at the end of the first control maneuver, cells were superfused with $10 \mu \mathrm{M}$ PMA and 4 min later with PMA + glucagon. A second $\mathrm{Cl}^{-}$removal/readmission maneuver was then performed and findings compared with the first control maneuver ( $n=13$; Table IV, Fig. 3). During superfusion with glucagon + PMA, the net $\mathrm{pH}_{\mathrm{i}}$ increase after $\mathrm{Cl}^{-}$removal $(0.22 \pm 0.05 \mathrm{pH} \mathrm{U})$, the rate of alkalinization after $\mathrm{Cl}^{-}$removal $\left(0.070 \pm 0.034 \mathrm{pH} \mathrm{U} / \mathrm{min} ; \mathrm{H}^{+}\right.$flux $\left.=3.98 \pm 1.02 \mathrm{mM} / \mathrm{min}\right)$ and the rate of $\mathrm{pH}_{\mathrm{i}}$ recovery after $\mathrm{Cl}^{-}$readmission $(0.130 \pm 0.063$ $\mathrm{pH} \mathrm{U} / \mathrm{min} ; \mathrm{H}^{+}$flux $=7.05 \pm 3.17 \mathrm{mM} / \mathrm{min}$ ) were similar to control values (first control maneuver; Table IV; Fig. 3 ). These findings indicate that PMA blocks the glucagon stimulation of the activity of the $\mathrm{Cl}^{-} / \mathrm{HCO}_{3}^{-}$exchanger.

Effect of colchicine on the glucagon stimulation of the $\mathrm{Cl}^{-}$/ $\mathrm{HCO}_{3}^{-}$exchanger activity (Table IV, Fig. 4). To evaluate the role of the microtubular system on the basal and glucagonstimulated $\mathrm{Cl}^{-} / \mathrm{HCO}_{3}^{-}$exchange activity, IRHC were pretreated with the microtubular inhibitor colchicine $\left(10^{-5} \mathrm{M}\right)$ or with its inactive analogue, $\beta$-lumicolchicine $\left(10^{-5} \mathrm{M}\right)$, for 4-5 h. Two consecutive $\mathrm{Cl}^{-}$removal/readmission maneuvers were then performed, the second during superfusion with $200 \mathrm{nM}$ glucagon. Colchicine pretreatment $(n=10)$ significantly $(P<0.03)$ decreased the net $\mathrm{pH}_{\mathrm{i}}$ increase $(0.12 \pm 0.04 \mathrm{pH} \mathrm{U})$ and the rate of alkalinization after $\mathrm{Cl}^{-}$removal $(0.040 \pm 0.018 \mathrm{pH} \mathrm{U} / \mathrm{min}$; $\mathrm{H}^{+}$flux $=2.20 \pm 0.77 \mathrm{mM} / \mathrm{min}$ ) as well as the rate of $\mathrm{pH}_{\mathrm{i}}$ recovery after $\mathrm{Cl}^{-}$readmission $\left(0.054 \pm 0.014 \mathrm{pH} \mathrm{U} / \mathrm{min} ; \mathrm{H}^{+}\right.$ flux $=3.36 \pm 0.92 \mathrm{mM} / \mathrm{min}$ ) in comparison with $\beta$-lumicolchicine-pretreated cells $(n=10$; Table IV, Fig. 4). Moreover, during glucagon exposure in colchicine-pretreated cells, the net $\mathrm{pH}_{\mathrm{i}}$ increase $(0.22 \pm 0.08 \mathrm{pH} \mathrm{U})$ and the rate of alkalinization after $\mathrm{Cl}^{-}$removal $\left(0.107 \pm 0.035 \mathrm{pH} \mathrm{U} / \mathrm{min} ; \mathrm{H}^{+}\right.$flux 

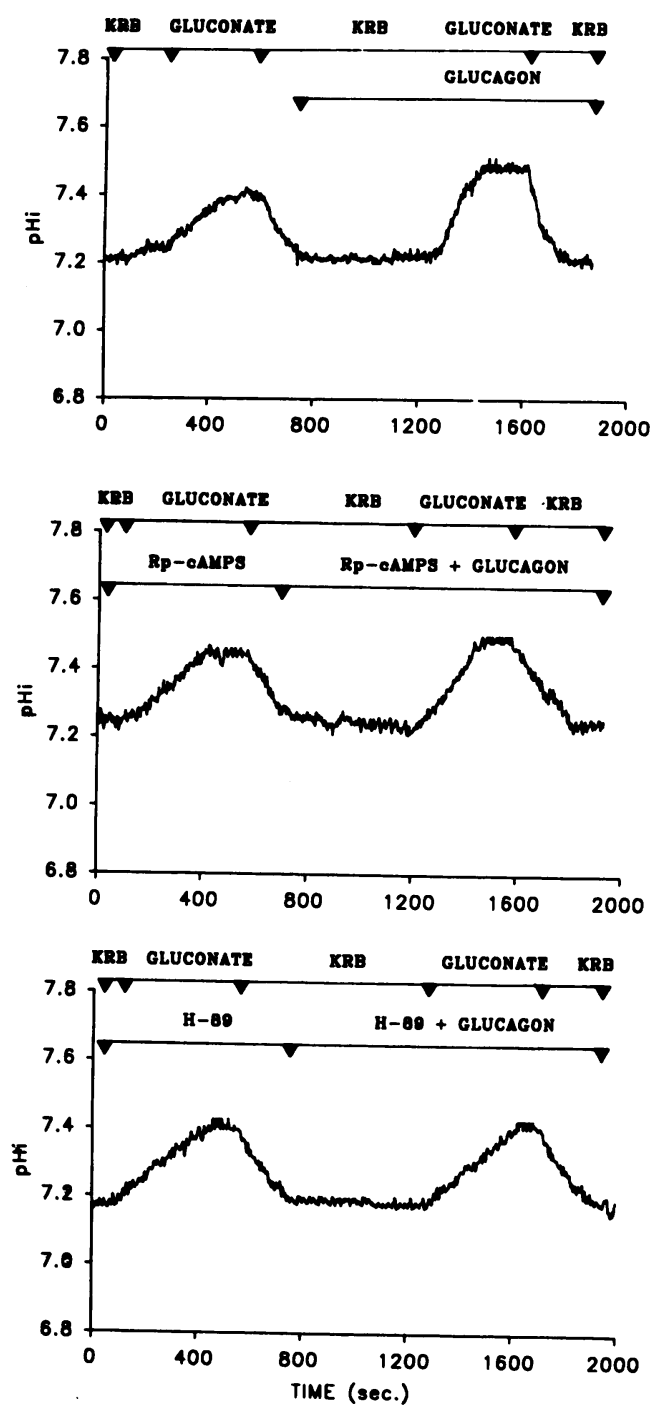

Figure 2. Effect of protein kinase A inhibitors (Rp-cAMPS, H-89) on $\mathrm{pH}_{\mathrm{i}}$ changes promoted by acute chloride removal and readmission in the absence or presence of glucagon. Two consecutive $\mathrm{Cl}^{-}$removal/ readmission maneuvers were performed, the second during superfusion with $200 \mathrm{nM}$ glucagon, in IRHC pretreated $(30 \mathrm{~min})$ and perfused with $10 \mu \mathrm{M}$ Rp-cAMPS ( $n=10$, middle tracing) or with $30 \mu \mathrm{M} \mathrm{H}-89$ ( $n$ $=10$, lower tracing). Data were compared with respect to control untreated IRHC ( $n=12$, upper tracing). The net $\mathrm{pH}_{\mathrm{i}}$ increase $\left(\delta \mathrm{pH}_{\mathrm{i}}\right)$ and the maximal rate of $\mathrm{pH}_{\mathrm{i}}$ increase after acute $\mathrm{Cl}^{-}$removal as well as the maximal rate of $\mathrm{pH}_{\mathrm{i}}$ recovery after $\mathrm{Cl}^{-}$readmission measured during the first maneuver (basal activity of the $\mathrm{Cl}^{-} / \mathrm{HCO}_{3}^{-}$exchanger) were not influenced by Rp-cAMPS nor by H-89. The same parameters measured in the presence of glucagon (second maneuver) were significantly higher in untreated IRHC with respect to IRHC treated with RpcAMPS or with H-89.

$=5.92 \pm 1.91 \mathrm{mM} / \mathrm{min}$ ) as well as the rate of $\mathrm{pH}_{\mathrm{i}}$ recovery after $\mathrm{Cl}^{-}$readmission $\left(0.120 \pm 0.034 \mathrm{pH} \mathrm{U} / \mathrm{min} ; \mathrm{H}^{+}\right.$flux $=7.14 \pm 2.99 \mathrm{mM} / \mathrm{min})$ were significantly $(P<0.02)$ lower in comparison with those measured during glucagon exposure in $\beta$-lumicolchicine-treated cells. However, colchicine-pretreated cells still responded to the hormone, since both the net $\mathrm{pH}_{\mathrm{i}}$ increase or the rate of alkalinization after $\mathrm{Cl}^{-}$removal and the rate of $\mathrm{pH}_{\mathrm{i}}$ recovery after $\mathrm{Cl}^{-}$readmission were significantly $(P$ $<0.05$ ) increased by glucagon exposure (second $\mathrm{Cl}^{-}$removal/ readmission maneuver) in comparison with control values (first
$\mathrm{Cl}^{-}$removal/readmission maneuver; Table IV, Fig. 4). These findings indicate that the inhibition of microtubular function decreased both the basal and glucagon-stimulated $\mathrm{Cl}^{-} / \mathrm{HCO}_{3}^{-}$ exchanger activity.

Effect of glucagon on the activity of the $\mathrm{Na}^{+}-\mathrm{HCO}_{3}^{-}$symport (Table I, Fig. 5). The activity of the $\mathrm{Na}^{+}-\mathrm{HCO}_{3}^{-}$symport was measured by evaluating the rate of recovery from $20 \mathrm{mM} \mathrm{NH}_{4} \mathrm{Cl}$ pulse in cells cultured and perfused with $\mathrm{HCO}_{3}^{-}$enriched media. This recovery is driven by two acid extruder mechanisms, the $\mathrm{Na}^{+} / \mathrm{H}^{+}$exchanger and the $\mathrm{Na}^{+}-\mathrm{HCO}_{3}^{-}$symport (6). To exclude the influence of the $\mathrm{Na}^{+} / \mathrm{H}^{+}$exchanger, when $\mathrm{NH}_{4} \mathrm{Cl}$ was withdrawn, cells were perfused with $1 \mathrm{mM}$ amiloride. When two consecutive $\mathrm{NH}_{4} \mathrm{Cl}$-amiloride pulses were performed $(n=7)$, no differences in the degree of acidification (nadir $\mathrm{pH}_{\mathrm{i}}$ ) and in the maximal rate of $\mathrm{pH}_{\mathrm{i}}$ recovery from the acid load were found. To investigate the effect of glucagon, a second $\mathrm{NH}_{4} \mathrm{Cl}$-amiloride pulse was performed during glucagon exposure, and the maximal rate of $\mathrm{pH}_{\mathrm{i}}$ recovery was compared with the first control pulse ( $n=8$; Table I, Fig. 5 ). Both the degree of acidification (nadir $\mathrm{pH}_{\mathrm{i}}=6.70 \pm 0.08$ ) and the maximal rate of recovery from $\mathrm{NH}_{4} \mathrm{Cl}^{-}$-amiloride pulse in the presence of glucagon were similar to the values measured in the absence of glucagon (nadir $\mathrm{pH}_{\mathrm{i}}=6.69 \pm 0.07$ ), indicating that the hormone has no effect on the activity of the $\mathrm{Na}^{+}-\mathrm{HCO}_{3}^{-}$ symport measured at acid $\mathrm{pH}_{\mathrm{i}}$ values.

The $\mathrm{Na}^{+}-\mathrm{HCO}_{3}^{-}$symport activity and the effect of glucagon were also evaluated at $\mathrm{pH}_{\mathrm{i}}$ values approaching the basal $\mathrm{pH}_{\mathrm{i}}$ of IRHC and in conditions where $\mathrm{Na}^{+} / \mathrm{H}^{+}$and $\mathrm{Cl}^{-} / \mathrm{HCO}_{3}^{-}$exchangers were blocked. For this purpose, cells were preincubated (40 min) and perfused with $\mathrm{Cl}^{-}$-free media (equimolar substitution with gluconate). In these experimental conditions, IRHC showed a higher $(P<0.01)$ basal $\mathrm{pH}_{\mathrm{i}}(7.40 \pm 0.07)$ in comparison with cells incubated and perfused with media containing normal $\mathrm{Cl}^{-}$concentration, due to the blockade of the acid loader $\mathrm{Cl}^{-} / \mathrm{HCO}_{3}^{-}$exchanger. When $\mathrm{Cl}^{-}$-depleted IRHC were submitted to a $15 \mathrm{mM} \mathrm{NH}_{4}^{+}$acid pulse and amiloride was administered at the moment of $\mathrm{NH}_{4}^{+}$withdrawal, nadir acidification (7.12 \pm 0.02 ) was close to the basal $\mathrm{pH}_{\mathrm{i}}$ of IRHC in medium containing normal $\mathrm{Cl}^{-}$concentration (7.19 \pm 0.07$)$. If $\mathrm{H}_{2}$-DIDS $(0.5 \mathrm{mM})$ was administered together with amiloride at the moment of $\mathrm{NH}_{4}^{+}$withdrawal $(n=4)$, the recovery from the acid load was completely abolished, indicating that the entrance of $\mathrm{HCO}_{3}^{-}$is responsible for this $\mathrm{pH}_{\mathrm{i}}$ recovery.

Two consecutive $15 \mathrm{mM} \mathrm{NH}_{4}^{+}$pulses were performed, the second during glucagon exposure and, at the moment of $\mathrm{NH}_{4}^{+}$ withdrawal, amiloride was superfused to exclude the influence of the $\mathrm{Na}^{+} / \mathrm{H}^{+}$exchanger $(n=8$; Table I, Fig. 5). In these experimental conditions, glucagon significantly $(P<0.03)$ stimulated the maximal rate of $\mathrm{pH}_{\mathrm{i}}$ recovery $(0.086 \pm 0.018 \mathrm{pH}$ $\mathrm{U} / \mathrm{min} ; \mathrm{JH}^{+}=4.49 \pm 1.20 \mathrm{mM} / \mathrm{min}$ ) from the $\mathrm{NH}_{4}^{+}$acid load (nadir $\mathrm{pH}_{\mathrm{i}}=7.13 \pm 0.02$ ) with respect to control values (first pulse: nadir $\mathrm{pH}_{\mathrm{i}}=7.12 \pm 0.02$; recovery rate $=0.063 \pm 0.016$ $\mathrm{pH} \mathrm{U} / \mathrm{min} ; \mathrm{JH}^{+}=3.28 \pm 0.82 \mathrm{mM} / \mathrm{min}$ ). This indicates that glucagon stimulates the activity of $\mathrm{Na}^{+}-\mathrm{HCO}_{3}^{-}$symport at basal $\mathrm{pH}_{\mathrm{i}}$.

cAMP levels in isolated rat hepatocytes (Fig. 6). Fig. 6 shows the cAMP levels in isolated rat hepatocytes, incubated with glucagon, agonists, or inhibitors, under the same conditions as those for the $\mathrm{pH}_{\mathrm{i}}$ measurement in IRHC. Exposure to 200 $\mathrm{nM}$ glucagon for $5 \mathrm{~min}$ increases cAMP levels sevenfold (from $0.98 \pm 0.35$ to $6.8 \pm 2.4 \mathrm{pmol} / 10^{6}$ cells; $\left.P<0.001\right)$. Pretreatment with the protein kinase A inhibitor H-89 (30 $\mu \mathrm{M})$ for 40 
Table IV. Effect of NPPB, PMA, or Colchicine on Basal and Glucagon-stimulated Chloride/Bicarbonate Exchanger Activity

\begin{tabular}{|c|c|c|c|c|c|c|}
\hline & \multirow[b]{2}{*}{ Basal $\mathrm{pH}_{\mathrm{i}}$} & \multicolumn{3}{|c|}{$\mathrm{Cl}^{-}$removal } & \multicolumn{2}{|c|}{$\mathrm{Cl}^{-}$readmission } \\
\hline & & $\delta \mathrm{pH}_{\mathrm{i}}$ & $\mathrm{pH} \mathrm{U} / \mathrm{min}$ & $\mathrm{H}^{+}$flux & $\mathrm{pH} \mathrm{U} / \mathrm{min}$ & $\mathbf{H}^{+}$flux \\
\hline & & $p H U$ & & $m M / \min$ & & $m M / \min$ \\
\hline Controls $(n=7)$ & $7.22 \pm 0.05$ & $0.21 \pm 0.05$ & $0.062 \pm 0.039$ & $3.36 \pm 1.17$ & $0.115 \pm 0.039$ & $6.92 \pm 2.22$ \\
\hline NPPB & $7.21 \pm 0.06$ & $0.20 \pm 0.06$ & $0.060 \pm 0.032$ & $3.16 \pm 1.06$ & $0.103 \pm 0.069$ & $6.22 \pm 2.01$ \\
\hline Controls $(n=7)$ & $7.21 \pm 0.04$ & $0.19 \pm 0.04$ & $0.067 \pm 0.030$ & $3.36 \pm 1.07$ & $0.120 \pm 0.035$ & $7.22 \pm 2.42$ \\
\hline Glucagon + NPPB & $7.20 \pm 0.04$ & $0.27 \pm 0.05 *$ & $0.157 \pm 0.052 *$ & $9.34 \pm 3.16^{*}$ & $0.197 \pm 0.089 *$ & $13.40 \pm 6.59^{*}$ \\
\hline Controls $(n=7)$ & $7.21 \pm 0.09$ & $0.22 \pm 0.06$ & $0.058 \pm 0.018$ & $3.48 \pm 1.07$ & $0.102 \pm 0.050$ & $6.14 \pm 2.86$ \\
\hline PMA & $7.20 \pm 0.08$ & $0.21 \pm 0.07$ & $0.060 \pm 0.034$ & $3.58 \pm 1.10$ & $0.109 \pm 0.059$ & $6.34 \pm 2.87$ \\
\hline Controls $(n=13)$ & $7.19 \pm 0.05$ & $0.20 \pm 0.04$ & $0.061 \pm 0.020$ & $3.28 \pm 0.87$ & $0.110 \pm 0.050$ & $6.64 \pm 3.06$ \\
\hline Glucagon + PMA & $7.20 \pm 0.05$ & $0.22 \pm 0.05$ & $0.070 \pm 0.034$ & $3.98 \pm 1.02$ & $0.130 \pm 0.063$ & $7.05 \pm 3.17$ \\
\hline$\beta$-Lumicolchicine controls $(n=10)$ & $7.20 \pm 0.06$ & $0.21 \pm 0.04$ & $0.068 \pm 0.018$ & $3.48 \pm 0.97$ & $0.110 \pm 0.050$ & $6.79 \pm 3.22$ \\
\hline$\beta$-Lumicolchicine + glucagon & $7.21 \pm 0.08$ & $0.29 \pm 0.07 *$ & $0.147 \pm 0.035^{*}$ & $8.02 \pm 1.91^{*}$ & $0.160 \pm 0.054^{\ddagger}$ & $11.87 \pm 5.42^{\ddagger}$ \\
\hline Colchicine controls $(n=10)$ & $7.23 \pm 0.04$ & $0.12 \pm 0.04^{8}$ & $0.040 \pm 0.018^{8}$ & $2.20 \pm 0.77^{8}$ & $0.054 \pm 0.014^{\S}$ & $3.36 \pm 0.92^{8}$ \\
\hline Colchicine + glucagon & $7.21 \pm 0.05$ & $0.22 \pm 0.08 * \|$ & $0.107 \pm 0.035 * \|$ & $5.92 \pm 1.91 * \|$ & $0.120 \pm 0.034^{\ddagger \|}$ & $7.14 \pm 2.99^{ \pm 11}$ \\
\hline
\end{tabular}

To evaluate the effect of NPPB or PMA on the basal and glucagon-stimulated $\mathrm{Cl}^{-} / \mathrm{HCO}_{3}^{-}$exchanger activity, two consecutive $\mathrm{Cl}^{-}$removal/ readmission maneuvers were performed, the second during superfusion with NPPB alone $(10 \mu \mathrm{M}, n=7)$, NPPB $(10 \mu \mathrm{M})+200 \mathrm{nM}$ glugacon $(n$ = 7), PMA alone $(10 \mu \mathrm{M}, n=7)$, or PMA $(10 \mu \mathrm{M})+200 \mathrm{nM}$ glucagon $(n=13)$. The net $\mathrm{pH}_{\mathrm{i}}$ increase $\left(\delta \mathrm{pH}_{\mathrm{i}}\right)$ and the maximal rate of $\mathrm{pH}_{\mathrm{i}}$ increase after acute $\mathrm{Cl}^{-}$removal as well as the maximal rate of $\mathrm{pH}_{\mathrm{i}}$ recovery after $\mathrm{Cl}^{-}$readmission were compared between the first (control) and the second (agonist or inhibitor with or without glucagon) acute $\mathrm{Cl}^{-}$removal/readmission maneuver. To evaluate the effect of colchicine on the basal and glucagon-stimulated $\mathrm{Cl}^{-} / \mathrm{HCO}_{3}^{-}$exchanger activity, two consecutive $\mathrm{Cl}^{-}$removal/readmission maneuvers were performed in cells pretreated with colchicine $\left(10^{-5} \mathrm{M}, 4-5 \mathrm{~h}\right)$, the second during superfusion with glucagon $(200 \mathrm{nM}, n=10)$. Findings were compared with $\beta$-lumicolchicinepretreated cells $(n=10)$. Data are means \pm SD. ${ }^{*} P<0.02$ vs. control values. ${ }^{\ddagger} P<0.05$ vs. control values. ${ }^{\S} P<0.03$ vs. $\beta$-lumicolchicine control values. "P $P$.02 vs. $\beta$-lumicolchicine glucagon values.

min did not significantly influence basal cAMP levels nor the cAMP increase induced by exposure to $200 \mathrm{nM}$ glucagon for $5 \mathrm{~min}$. Nor did the $\mathrm{Cl}^{-}$channel blocker, NPPB (10 $\mu \mathrm{M} ; 10$ min) significantly change the basal or glucagon-stimulated cAMP levels. The protein kinase $\mathrm{C}$ agonist, PMA (10 $\mu \mathrm{M}, 5$ min of incubation), did not significantly change the basal cAMP levels but cells incubated with PMA for $4 \mathrm{~min}$ before exposure to $200 \mathrm{nM}$ glucagon ( $5 \mathrm{~min}$ ) exhibited 55\% lower cAMP levels $\left(3.06 \pm 1.03 \mathrm{pmol} / 10^{6}\right.$ cells) with respect to glucagon-stimulated controls $\left(6.8 \pm 2.4 \mathrm{pmol} / 10^{6}\right.$ cells; $\left.P<0.01\right)$. Colchicine pretreatment $\left(10^{-5} \mathrm{M} ; 5 \mathrm{~h}\right)$ failed to significantly influence the accumulation of cAMP induced by $200 \mathrm{nM}$ glucagon with respect to $\beta$-lumicolchicine-treated cells. cAMP levels were not determined in cells treated with Rp-cAMPS or with DBcAMP because these two compounds interfere with the cAMP assay system.

\section{Discussion}

Ion transport processes involved in $\mathrm{pH}_{\mathrm{i}}$ regulation have been defined previously in rat hepatocyte subconfluent monolayers $(6-8)$. In our study, $\mathrm{pH}_{\mathrm{i}}$ measurement was performed in polarized IRHC, using a single cell microfluorimetric equipment. This method has the advantage of recording the signal from a polarized cell system, which represents the functional secretory unit in the liver (5), rather than averaging the signal from a whole cell population, containing either polarized or nonpolarized cells. Furthermore, viability of IRHC was considerably higher than the whole cell population and was less variable between different cell preparations. Consistent with the above, the activities of transport processes involved in $\mathrm{pH}_{\mathrm{i}}$ regulation measured in IRHC were higher than those reported in subconfluent rat hepatocyte monolayers (6-8).

Effect of glucagon on the $\mathrm{Cl}^{-} / \mathrm{HCO}_{3}^{-}$exchanger activity. In all the cell types studied $(7,8,11-15,18,24,27-30)$, the $\mathrm{Cl}^{-} / \mathrm{HCO}_{3}^{-}$exchanger has been shown to work as an acid loader driven by the $\mathrm{Cl}^{-}$gradient. As an acid loader, this exchanger functions as a counterpoint to the acid extruder systems in the $\mathrm{pH}_{\mathrm{i}}$ regulation on hepatocytes (6-8). The $\mathrm{Cl}^{-} / \mathrm{HCO}_{3}^{-}$exchanger was first identified in canalicular rat liver plasma membrane vesicles (35), then in monolayer culture of isolated hepatocytes (7) and recently it has been detected immunohistochemically in the hepatocyte apical domain of human liver (9). The two acid extruders, $\mathrm{Na}^{+}-\mathrm{HCO}_{3}^{-}$symport and $\mathrm{Na}^{+} / \mathrm{H}^{+}$exchanger, in addition to isolated rat hepatocytes (6), have also been identified in rat hepatocyte basolateral membrane vesicles $(36,37)$. It could thus be assumed that in the polarized IRHC, the $\mathrm{Cl}^{-} / \mathrm{HCO}_{3}^{-}$exchanger is located on the apical side and the two acid extruders are located on the basolateral side. Electrophysiological studies on IRHC have demonstrated that the resistances of tight junctions that seal the canalicular lumen from the bathing media are comparable with those of leaky epithelia and allow rapid ion equilibration between these two compartments (38). This implies that the behavior of the $\mathrm{Cl}^{-} / \mathrm{HCO}_{3}^{-}$ in response to $\mathrm{Cl}^{-}$removal/readmission from the bathing media should be the same whether the exchanger is restricted to the canalicular domain of IRHC or not.

In the isolated perfused rat liver, stimulation of $\mathrm{Cl}^{-}$/ $\mathrm{HCO}_{3}^{-}$exchanger by intracellular alkalinization induces a bicarbonate-rich choleresis, thereby suggesting the involvement of 

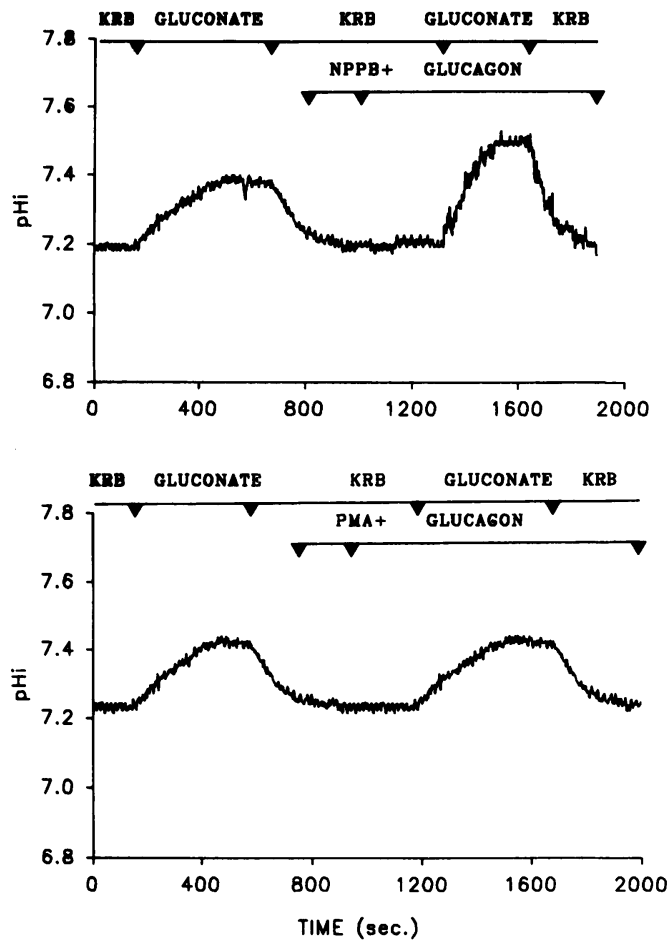

Figure 3. Effect of NPPB or PMA on glucagon-stimulated $\mathrm{pH}_{\mathrm{i}}$ changes promoted by acute chloride removal and readmission. (Upper tracing) After the first control $\mathrm{Cl}^{-}$removal/readmission (equimolar substitution with gluconate) maneuver, IRHC was perfused with the chloride channel blocker NPPB $(10 \mu \mathrm{M})$ and later with NPPB $+200 \mathrm{nM}$ glucagon. A second $\mathrm{Cl}^{-}$removal/readmission maneuver was then performed ( $n$ $=7$ ). During superfusion with glucagon $+\mathrm{NPPB}$, the net $\mathrm{pH}_{\mathrm{i}}$ increase and the rate of alkalinization after $\mathrm{Cl}^{-}$removal as well as the rate of $\mathrm{pH}_{\mathrm{i}}$ recovery after $\mathrm{Cl}^{-}$readmission were significantly higher than control values. (Lower tracing) After the first control $\mathrm{Cl}^{-}$removal/readmission maneuver, IRHC was perfused with the protein kinase $\mathrm{C}$ agonist, PMA $(10 \mu \mathrm{M})$, and later with PMA $+200 \mathrm{nM}$ glucagon. A second $\mathrm{Cl}^{-}$removal/readmission maneuver was then performed $(n=13)$. During superfusion with glucagon $+\mathrm{PMA}$, the net $\mathrm{pH}_{\mathrm{i}}$ increase and the rate of alkalinization after $\mathrm{Cl}^{-}$removal as well as the rate of $\mathrm{pH}_{\mathrm{i}}$ recovery after $\mathrm{Cl}^{-}$readmission were similar with respect to control values.

this exchanger in bicarbonate excretion in bile and in the generation of bile salt-independent canalicular bile flow (20). We demonstrated that glucagon stimulates the activity of the $\mathrm{Cl}^{-} /$ $\mathrm{HCO}_{3}^{-}$exchanger, a mechanism which could sustain the bicarbonate-rich choleresis induced by this hormone. Glucagon increased the rate of $\mathrm{Cl}^{-} / \mathrm{HCO}_{3}^{-}$exchange by $100 \%$ when measured during $\mathrm{Cl}^{-}$removal or by $50 \%$ after $\mathrm{Cl}^{-}$readmission. In comparison, the excretion rates of bicarbonate in bile were increased by $34 \%$ in the rat (4) and by $71 \%$ in the guinea pig (2).

A number of studies have shown previously that glucagon, after stimulation of adenylate cyclase activity, increased the intracellular level of cAMP in isolated rat hepatocytes (31), in the isolated perfused rat (39), and in guinea pig liver (2). By extrapolating measurements of the entire preparation of isolated rat hepatocytes, the concentration of glucagon used to stimulate the $\mathrm{Cl}^{-} / \mathrm{HCO}_{3}^{-}$exchange in IRHC induces an almost maximal increase of cAMP levels. That cAMP is the intracellular messenger mediating the glucagon-induced bicarbonate biliary excretion was shown previously in the isolated perfused guinea pig liver (2), where a bicarbonate-rich choleresis was induced
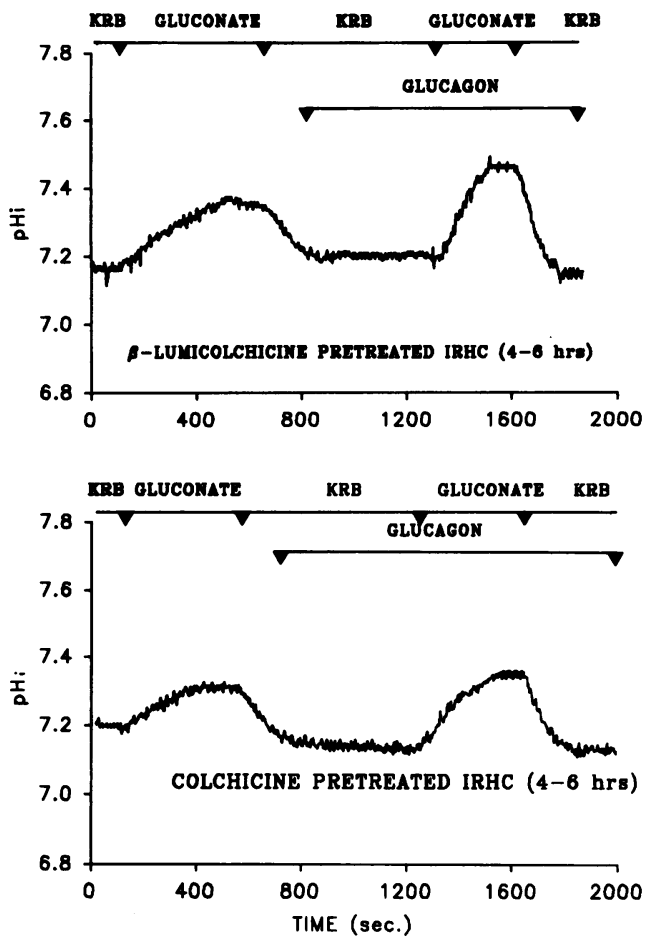

Figure 4. Effect of colchicine on $\mathrm{pH}_{\mathrm{i}}$ changes promoted by acute chloride removal and readmission in basal conditions and during glucagon exposure. IRHC were pretreated with colchicine $\left(4-5 \mathrm{~h}, 10^{-5} \mathrm{M}, n=\right.$ $10)$ or with its inactive analogue ( $\beta$-lumicolchicine, $n=10$ ) in bicarbonate-containing media. Two consecutive $\mathrm{Cl}^{-}$removal/readmission (equimolar substitution with gluconate) maneuvers were then performed, the second during superfusion with $200 \mathrm{nM}$ glucagon. The net $\mathrm{pH}_{\mathrm{i}}$ increase $\left(\delta \mathrm{pH}_{\mathrm{i}}\right)$ and the maximal rate of $\mathrm{pH}_{\mathrm{i}}$ increase after acute $\mathrm{Cl}^{-}$removal as well as the maximal rate of $\mathrm{pH}_{\mathrm{i}}$ recovery after $\mathrm{Cl}^{-}$ readmission were significantly lower in colchicine- than in $\beta$-lumicolchicine-treated IRHC, either in basal conditions (first maneuver) or during glucagon exposure.

by glucagon but not by a glucagon analogue, TH-glucagon, which did not increase the intracellular level of cAMP. In addition, in the perfused rat liver, DBcAMP induced a bicarbonaterich choleresis (40). Our finding that DBcAMP + forskolin completely mimics the stimulatory effect of glucagon on $\mathrm{Cl}^{-}$/ $\mathrm{HCO}_{3}^{-}$exchange strongly suggests that this hormone enhances the bicarbonate excretion in bile via cAMP-mediated stimulation of an apically located (9) $\mathrm{Cl}^{-} / \mathrm{HCO}_{3}^{-}$exchanger. This is in keeping with studies concerning a number of different bicarbonate-secreting epithelia, where the intracellular messenger cAMP appears to stimulate the $\mathrm{HCO}_{3}^{-}$excretion mediated by the $\mathrm{Cl}^{-} / \mathrm{HCO}_{3}^{-}$exchanger $(10-13,17,18)$. We then investigated the involvement of protein kinase $\mathrm{A}$ in the glucagon stimulation of the $\mathrm{Cl}^{-} / \mathrm{HCO}_{3}^{-}$exchanger activity using two different protein kinase A inhibitors, Rp-cAMPS and H-89. Rp-cAMPS is a distereomer of an analogue of natural cAMP which binds to the regulatory subunit of both type I and type II cAMPdependent protein kinase without dissociating the catalytic subunit (41). Rp-cAMPS is also a poor substrate for several phosphodiesterases (42). In rat hepatocytes, Rp-cAMPS inhibited glucagon-induced glycogenolysis, a cAMP-mediated effect (43). H-89, a recently synthesized isoquinolimesulfonamide, exhibited selective and potent inhibition on protein kinase A (44). Cells were preincubated and then perfused with RpcAMPS or with $\mathrm{H}-89$, as indicated by previous studies, to 

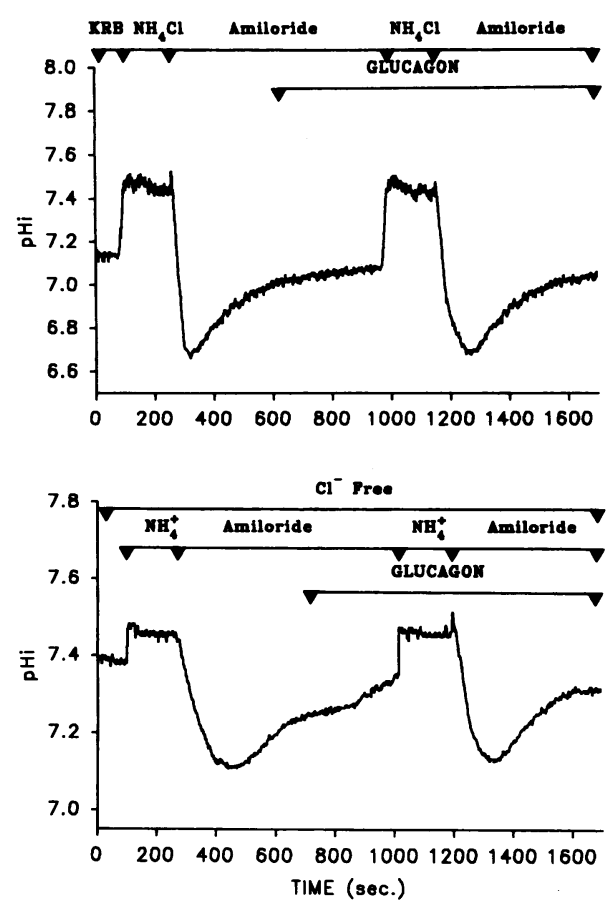

Figure 5. Effect of glucagon on the rate of $\mathrm{pH}_{\mathrm{i}}$ recovery from an acute acid load in normal or chloride-depleted IRHC. (Upper tracing) In the presence of bicarbonate (KRB), two consecutive $20 \mathrm{mM} \mathrm{NH}_{4} \mathrm{Cl}$ pulses were performed, the second during exposure to $200 \mathrm{nM}$ glucagon $(n$ $=8$ ). At the moment of $\mathrm{NH}_{4} \mathrm{Cl}$ withdrawal, amiloride was superfused to exclude the influence of the $\mathrm{Na}^{+} / \mathrm{H}^{+}$exchanger. The degree of acidification and the rate of $\mathrm{pH}_{\mathrm{i}}$ recovery after $\mathrm{NH}_{4} \mathrm{Cl}$ withdrawal were not changed by glucagon. (Lower tracing) $\mathrm{Cl}^{-}$depletion was performed by preincubation $\left(40 \mathrm{~min}\right.$ ) and perfusion with $\mathrm{Cl}^{-}$-free media (equimolar substitution with gluconate). Two consecutive $15 \mathrm{mM} \mathrm{NH}_{4}^{+}$pulses were performed, the second during exposure to $200 \mathrm{nM}$ glucagon ( $n$ $=8$ ). At the moment of $\mathrm{NH}_{4}^{+}$withdrawal, amiloride was superfused to exclude the influence of the $\mathrm{Na}^{+} / \mathrm{H}^{+}$exchanger. Glucagon significantly increased the rate of $\mathrm{pH}_{\mathrm{i}}$ recovery from the acute acid load with respect to control values (first pulse).

achieve the maximal inhibitory effect on protein kinase A (43, $44)$. We demonstrated that the stimulatory effect of glucagon on $\mathrm{Cl}^{-} / \mathrm{HCO}_{3}^{-}$exchange was almost completely blocked by pretreatment and perfusion with Rp-cAMPS or with H-89. Both these inhibitors had no impact on basal $\mathrm{pH}_{\mathrm{i}}$, nor on the basal activity of the $\mathrm{Cl}^{-} / \mathrm{HCO}_{3}^{-}$exchanger and, at least with regard to $\mathrm{H}-89$, did not decrease the cAMP accumulation induced by glucagon in isolated hepatocytes. Thus, our findings indicate that protein kinase $\mathrm{A}$ is directly involved in the glucagon stimulation of the $\mathrm{Cl}^{-} / \mathrm{HCO}_{3}^{-}$exchange.

Epithelia that secrete $\mathrm{HCO}_{3}^{-}$via the $\mathrm{Cl}^{-} / \mathrm{HCO}_{3}^{-}$exchanger may regulate this secretory process by directly affecting the exchanger or, indirectly, by modifying the activity of $\mathrm{Cl}^{-}$channels. In the presence of an in-to-out directed electrochemical $\mathrm{Cl}^{-}$gradient, the activation of apically located $\mathrm{Cl}^{-}$channels increases the luminal $\mathrm{Cl}^{-}$concentration, thus favoring the gradient for the $\mathrm{Cl}^{-} / \mathrm{HCO}_{3}^{-}$exchange. To investigate whether the glucagon stimulation of the $\mathrm{Cl}^{-} / \mathrm{HCO}_{3}^{-}$exchange activity is a primary event or occurs secondary to $\mathrm{Cl}^{-}$channel activation, the effect of NPPB, a potent and specific $\mathrm{Cl}^{-}$channel blocker, was studied (34). We demonstrated that NPPB failed to influence either basal or glucagon-stimulated $\mathrm{Cl}^{-} / \mathrm{HCO}_{3}^{-}$exchange. This finding excludes that NPPB-sensitive $\mathrm{Cl}^{-}$channels are
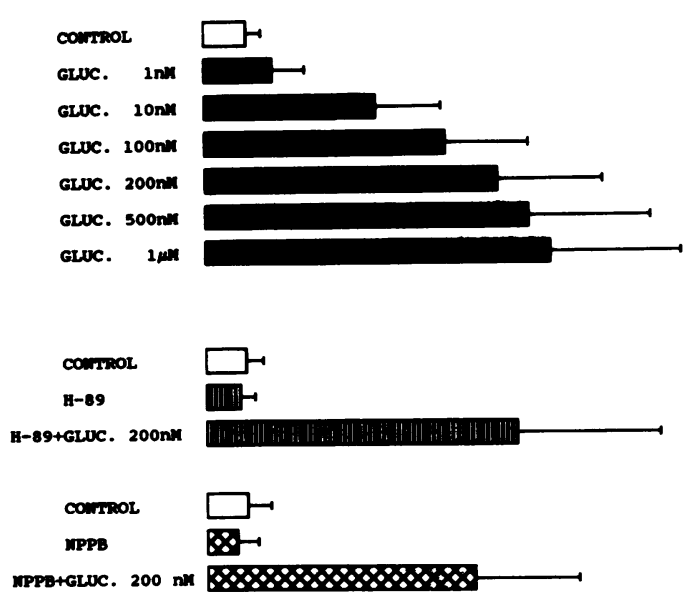

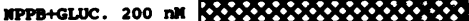
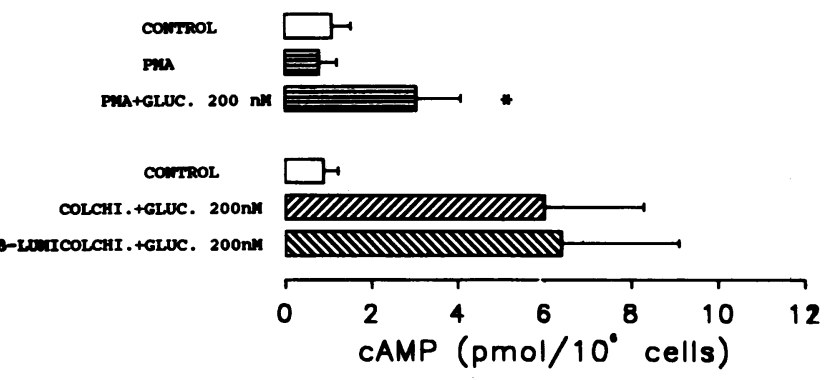

Figure 6. cAMP levels in isolated rat hepatocytes. Cells plated in 25 $\mathrm{mM}$ bicarbonate-containing media (KRB) were incubated with glucagon, agonists, or inhibitors, under the same conditions as those for the $\mathrm{pH}_{\mathrm{i}}$ measurement in IRHC. Cell exposed for $5 \mathrm{~min}$ to increased concentration (from $1 \mathrm{nM}$ to $1 \mu \mathrm{M}$ ) of glucagon (GLUC.) exhibited a progressive accumulation of cAMP, with a sevenfold enhancement of basal cAMP levels obtained at $200 \mathrm{nM}$ glucagon. Pretreatment with the protein kinase A inhibitor $\mathrm{H}-89(30 \mu \mathrm{M})$ for $40 \mathrm{~min}$ did not significantly influence basal cAMP levels nor cAMP increase induced by exposure to $200 \mathrm{nM}$ glucagon for $5 \mathrm{~min}$. The $\mathrm{Cl}^{-}$channel blocker, NPPB (10 $\mu \mathrm{M}$; 10-min incubation), did not significantly change the basal nor the glucagon-stimulated cAMP levels. The protein kinase C agonist, PMA ( 10 $\mu \mathrm{M}, 5-$ min incubation), did not significantly change the basal cAMP levels, but cells incubated with PMA for 4 min before exposure to 200 $\mathrm{nM}$ glucagon ( $5 \mathrm{~min}$ ) exhibited 55\% lower cAMP levels (3.06 \pm 1.03 $\mathrm{pmol} / 10^{6}$ cells) with respect to $200 \mathrm{nM}$ glucagon-stimulated controls $\left(6.8 \pm 2.4 \mathrm{pmol} / 10^{6}\right.$ cells; $\left.P<0.01\right)$. Colchicine (COLCHI.) pretreatment $\left(10^{-5} \mathrm{M} ; 5 \mathrm{~h}\right)$ failed to significantly influence the accumulation of cAMP induced by $200 \mathrm{nM}$ glucagon with respect to $\beta$-lumicolchicine ( $\beta$-LUMICOLCHI. $)$-treated cells. ${ }^{*} P<0.01$ vs. $200 \mathrm{nM}$ glucagon. Data are means \pm SD from duplicate measurements in $n=6$ cell preparations. Statistical analysis was conducted using ANOVA.

involved in glucagon stimulation of the exchanger. Different $\mathrm{Cl}^{-}$channels could, however, be involved also in light of a recent description, in rat liver canalicular plasma membranes, of two types (30- and 90-pS conductance) of $\mathrm{Cl}^{-}$channels with NPPB-insensitive conductance and kinetics (45).

In different cell types, several ion transport systems regulated by protein kinase A show inverse sensitivity to protein kinase $C(46,47)$. In the isolated perfused rat liver, protein kinase $\mathrm{C}$ agonists, phorbol esters, inhibit DBcAMP-stimulated bile flow (48) and, in isolated rat hepatocytes, they inhibit the $\mathrm{HCO}_{3}^{-}$- and DBcAMP-stimulated $\mathrm{Cl}^{-} / \mathrm{HCO}_{3}^{-}$exchanger activity (8). This prompted us to explore the role of protein kinase $\mathrm{C}$ in the glucagon stimulation of the $\mathrm{Cl}^{-} / \mathrm{HCO}_{3}^{-}$exchanger. We demonstrated that the phorbol ester, PMA, completely blocked 
the effect of glucagon on $\mathrm{Cl}^{-} / \mathrm{HCO}_{3}^{-}$exchanger activity but, however, this effect was achieved through a marked inhibition of the glucagon-induced cAMP accumulation in isolated hepatocytes. Although an additional effect at the level of the $\mathrm{Cl}^{-}$ $/ \mathrm{HCO}_{3}^{-}$exchanger cannot be excluded, our findings are consistent with a counterregulatory effect of protein kinase $C$, or PMA itself, at the level of glucagon receptors or adenylate cyclase. This is in keeping with previous studies showing that phorbol esters cause a dose-dependent inhibition of the glucagon-stimulated adenylate cyclase in plasma membranes isolated from rat hepatocytes, probably through protein kinase $\mathrm{C}$ activation and modification of the guanine nucleotide regulatory protein system (49).

The microtubular system is thought to be involved in many different transport processes in the liver as well as in the generation of bile flow (5). As far as glucagon choleresis is concerned, this is blocked by the microtubular inhibitor colchicine, which did not interfere with the metabolic effects or cAMP accumulation induced by the hormone (2). We found that both basal and glucagon-stimulated $\mathrm{Cl}^{-} / \mathrm{HCO}_{3}^{-}$exchange activities were inhibited by colchicine in comparison with $\beta$-lumicolchicine. However, in colchicine-treated cells, a glucagon stimulation of $\mathrm{Cl}^{-} / \mathrm{HCO}_{3}^{-}$exchanger is still present, although at a lower level than in $\beta$-lumicolchicine controls. The effect of colchicine occurred without influencing the glucagon-induced cAMP accumulation in isolated hepatocytes. These findings could be explained by the fact that the number of $\mathrm{Cl}^{-} / \mathrm{HCO}_{3}^{-}$units in the canalicular membranes was decreased by colchicine through a blockade of a microtubular-dependent targeting of vesicles containing the exchanger to the canalicular plasma membranes. Such regulatory mechanisms of the $\mathrm{Cl}^{-} / \mathrm{HCO}_{3}^{-}$exchanger have been proposed (8) after observations that colchicine inhibits the stimulation of the $\mathrm{Cl}^{-} / \mathrm{HCO}_{3}^{-}$exchanger induced by incubation of isolated hepatocytes in $\mathrm{HCO}_{3}^{-}$-containing media.

Effect of glucagon on $\mathrm{pH}_{i}$ regulation in IRHC. Despite the increased bicarbonate excretion via $\mathrm{Cl}^{-} / \mathrm{HCO}_{3}^{-}$activation, glucagon showed no effect on basal $\mathrm{pH}_{\mathrm{i}}$ of IRHC. The maintenance of basal $\mathrm{pH}_{\mathrm{i}}$, despite the increased bicarbonate excretion via $\mathrm{Cl}^{-} / \mathrm{HCO}_{3}^{-}$exchange stimulation, indicates that a compensatory mechanism in the cell is, in parallel, activated by glucagon. We investigated whether glucagon stimulation of the acid loading mechanism $\left(\mathrm{Cl}^{-} / \mathrm{HCO}_{3}^{-}\right.$exchanger $)$is balanced by an increased activity of acid extruders. We have excluded an effect of glucagon on the $\mathrm{Na}^{+} / \mathrm{H}^{+}$exchanger both when the activity of this acid extruder was measured at basal $\mathrm{pH}_{\mathrm{i}}$ (amiloride exposure withdrawal) and after an acute acid load. The other acid extruding system, $\mathrm{Na}^{+}-\mathrm{HCO}_{3}^{-}$symport, was not stimulated by glucagon at acid $\mathrm{pH}_{\mathrm{i}}$, as evaluated by the recovery rate from an acute acid load in $\mathrm{KRB}\left(20 \mathrm{mM} \mathrm{NH}_{4} \mathrm{Cl}\right)$ and in the presence of amiloride (nadir $\mathrm{pH}=6.7$ ). However, since the stimulatory effect of glucagon on the $\mathrm{Cl}^{-} / \mathrm{HCO}_{3}^{-}$was demonstrated at basal $\mathrm{pH}_{\mathrm{i}}\left(\mathrm{Cl}^{-}\right.$removal $)$or at higher $\mathrm{pH}_{\mathrm{i}}$ values $\left(\mathrm{Cl}^{-}\right.$readmission $)$, we tried to use a protocol whereby the activity of the $\mathrm{Na}^{+}$$\mathrm{HCO}_{3}^{-}$symport and the effect of glucagon could be measured at $\mathrm{pH}_{\mathrm{i}}$ values close to basal $\mathrm{pH}_{\mathrm{i}}$ of IRHC. Indeed, when we measured the recovery rate from a $15 \mathrm{mM} \mathrm{NH}_{4}$ acid load in $\mathrm{Cl}^{-}$-depleted and amiloride-perfused IRHC (nadir $\mathrm{pH}_{\mathrm{i}}=7.13$ ) a significant stimulation by glucagon was observed. It was demonstrated previously, in $\mathrm{Cl}^{-}$-depleted and amiloride-perfused hepatocyte monolayers, that the recovery from an acute acid load is driven by the $\mathrm{Na}^{+}-\mathrm{HCO}_{3}^{-}$symport (6), which is the major acid extruding mechanism in the presence of bicarbonate.

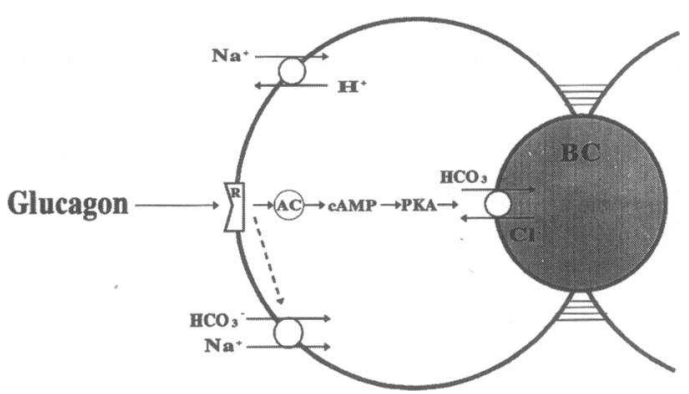

Figure 7. Proposed mechanisms of glucagon stimulation of the $\mathrm{Cl}^{-} / \mathrm{HCO}_{3}^{-}$exchanger activity in IRHC. The figure shows the two acid extruders $\left(\mathrm{Na}^{+}-\mathrm{H}^{+}\right.$exchanger and $\mathrm{Na}^{+}-\mathrm{HCO}_{3}^{-}$symport $)$located on the basolateral side and the acid loader $\left(\mathrm{Cl}^{-} / \mathrm{HCO}_{3}^{-}\right.$exchanger $)$on the canalicular side of one of the two hepatocytes forming a couplet. $B C$, bile canaliculus. After binding to receptor $(R)$, glucagon stimulates adenylate cyclase $(A C)$ and enhances cAMP levels which, through protein kinase $\mathrm{A}(P K A)$, increases the activity of the apically located $\mathrm{Cl}^{-} / \mathrm{HCO}_{3}^{-}$. exchanger. Despite the glucagon-stimulated bicarbonate excretion, resting $\mathrm{pH}_{\mathrm{i}}$ of hepatocytes remains unchanged because of the parallel increase of bicarbonate loading through the stimulation of $\mathrm{Na}^{+}-\mathrm{HCO}_{3}^{-}$symport (dotted-line arrow). The $\mathrm{Na}^{+} / \mathrm{H}^{+}$exchanger was unaffected by glucagon.

We further observed how, in these experimental conditions, the $\mathrm{pH}_{\mathrm{i}}$ recovery from acid load is completely abolished by $\mathrm{H}_{2}-$ DIDS, evidence that $\mathrm{HCO}_{3}^{-}$entrance is involved. Thus, our findings indicate that glucagon stimulates bicarbonate loading throughout the $\mathrm{Na}^{+}-\mathrm{HCO}_{3}^{-}$symport but that this takes place only at basal $\mathrm{pH}_{\mathrm{i}}$ and not at acid $\mathrm{pH}_{\mathrm{i}}$ values. $\mathrm{A} \mathrm{pH}$ dependence of the $\mathrm{Na}^{+}-\mathrm{HCO}_{3}^{-}$symport and of its regulation, demonstrated recently in basolateral membrane vesicles isolated from rabbit renal cortex (50), could explain this finding. On the other hand, the glucacon stimulation of this symport occurred in $\mathrm{Cl}^{-}$-depleted cells, a condition where the $\mathrm{Cl}^{-} / \mathrm{HCO}_{3}^{-}$exchanger is almost entirely blocked. This indicates that $\mathrm{HCO}_{3}^{-}$entrance is stimulated by the hormone independently and not as a consequence of increased bicarbonate extrusion via $\mathrm{Cl}^{-} / \mathrm{HCO}_{3}^{-}$exchanger. The $\mathrm{Na}^{+}-\mathrm{HCO}_{3}^{-}$symport could be stimulated subsequent to the increased $\mathrm{Na}^{+}$gradient induced by glucagon stimulation of $\left(\mathrm{Na}^{+}-\mathrm{K}^{+}\right)$-ATPase, an effect already demonstrated in isolated hepatocytes $(51)$.

The conclusions of our study are outlined in Fig. 7. Glucagon enhances cAMP levels which in turn, through protein kinase A, stimulate the $\mathrm{Cl}^{-} / \mathrm{HCO}_{3}^{-}$exchanger. This mechanism could account for in vivo induced bicarbonate-rich choleresis. Glucagon induces an upregulation of the $\mathrm{pH}_{\mathrm{i}}$ regulatory mechanisms operating in the presence of bicarbonate since the activity of the bicarbonate loading system, $\mathrm{Na}^{+}-\mathrm{HCO}_{3}^{-}$symport, is also stimulated, thus avoiding changes of resting $\mathrm{pH}_{\mathrm{i}}$. We have also shown that glucagon stimulation of the $\mathrm{Cl}^{-} / \mathrm{HCO}_{3}^{-}$exchange is not mediated by NPPB-sensitive chloride channels, requires an intact microtubule system, and is counterregulated by the protein kinase $\mathrm{C}$ agonist, PMA, which blocks the cAMP accumulation induced by the hormone.

From a physiologic point of view, molecular mechanisms of glucagon-induced bicarbonate excretion should mainly operate in the fasting state in relationship to the raised serum level of the hormone. In these conditions, the bicarbonate excretion stimulated by the hormone may well play an important role as an osmotic driving force for canalicular bile formation since bile salt biliary secretion is at the minimal rate. 


\section{Acknowledgments}

The authors thank Prof. S. Adamo and Dr. F. Folli for helpful discussions and Mrs. Joan Crowley for manuscript preparation.

\section{References}

1. Forker, E. L. 1977. Mechanisms of hepatic bile formation. Annu. Rev. Physiol. 39:323-347.

2. Lenzen, R., V. J. Hruby, and N. Tavoloni. 1990. Mechanism of glucagon choleresis in guinea pigs. Am. J. Physiol. 259:G736-G744.

3. Khedis, A., M. Dumont, and S. Erlinger. 1974. Influence of glucagon on canalicular bile production in the dog. Biomedicine (Paris). 21:176-181.

4. Thomsen, O. O., and J. A. Larsen. 1981. The effect of glucagon, dibutyryl cyclic AMP, and insulin on bile production in the intact rat and the perfused rat liver. Acta Physiol. Scand. 111:23-30.

5. Nathanson, H. M., and J. L. Boyer. 1991. Mechanisms and regulation of bile secretion. Hepatology. 14:551-566.

6. Gleeson, D., N. D. Smith, and J. L. Boyer. 1989. Bicarbonate-dependent and -independent intracellular $\mathrm{pH}$ regulatory mechanisms in rat hepatocytes. Evidence for $\mathrm{Na}^{+}: \mathrm{HCO}_{3}^{-}$cotransport. J. Clin. Invest. 84:312-321.

7. Benedetti, A., M. Strazzabosco, J. C. Corasanti, P. Haddad, J. Graf, and J. L. Boyer. 1991. $\mathrm{Cl}^{-} / \mathrm{HCO}_{3}^{-}$exchanger in isolated rat hepatocytes: role in regulation of intracellular pH. Am. J. Physiol. 261:G512-G522.

8. Benedetti, A., M. Strazzabosco, O. C. Ng., and J. L. Boyer. 1994. Regulation of activity and apical targeting of the $\mathrm{Cl}^{-} / \mathrm{HCO}_{3}^{-}$exchanger in rat hepatocytes. Proc. Natl. Acad. Sci. USA. 91:792-796.

9. MartinesAnso, E., J. E. Castillo, J. Diez, J. F. Medina, and J. Prieto. 1994 Immunohistochemical detection of chloride/bicarbonate anion exchangers in human liver. Hepatology. 19:1400-1406.

10. Flemström, G., J. R. Heylings, and A. Garner. 1982. Gastric and duodenal $\mathrm{HCO}_{3}^{-}$transport in vitro: effects of hormones and local transmitters. Am. J. Physiol. 242:G100-G110.

11. Case, R. M., and B. E. Argent. 1986. Bicarbonate secretion by pancreatic duct cells: mechanism and control. In The Exocrine Pancreas: Biology, Pathobiology, and Diseases. V. L. W. Go, J. D. Gardner, F. P. Brooks, E. Lebenthal, E. P. Di Magno, and G. A. Scheele, editors. Raven Press, New York. 213-243.

12. Gray, M. A., J. R. Greenwell, and B. E. Argent. 1988. Secretin-regulated chloride channel on the apical plasma membrane of pancreatic duct cells. $J$. Membr. Biol. 105:131-142.

13. Novak, I., and R. Greger. 1988. Properties of the luminal membrane of isolated rat pancreatic ducts. Effect of cyclic AMP and blockers of chloride transport. Pflugers Archiv. 411:546-553.

14. Stuenkel, E. L., T. E. Machen, and J. A. Williams. 1988. pH regulatory mechanisms in rat pancreatic ductal cells. Am. J. Physiol. 254:G925-G930.

15. Stetson, D. L., R. Beauwens, J. Palmisano, P. P. Mitchell, and P. R. Steinmetz. 1985. A double-membrane model for urinary bicarbonate secretion. Am. J. Physiol. 249:F546-F552.

16. Sundaram, U., R. Knikelbein, and J. W. Dobbins. 1991. pH regulation in ileum: $\mathrm{Na}^{+}-\mathrm{H}^{+}$and $\mathrm{Cl}^{-} / \mathrm{HCO}_{3}^{-}$exchange in isolated crypt and villus cells. Am. J. Physiol. 260:G440-G449.

17. Schuster, V. L. 1985. Cyclic adenosine monophosphate-stimulated bicarbonate secretion in rabbit cortical collecting tubules. J. Clin. Invest. 75:20562064.

18. Alvaro, D., W. K. Cho, A. Mennone, and J. L. Boyer. 1993. Effect of secretin on intracellular $\mathrm{pH}$ regulation in isolated rat bile duct epithelial cells. $J$. Clin. Invest. 92:1314-1325.

19. Fitz, J. G., S. Basavappa, J. M. McGill, O. Mehlus, and J. A. Cohn. 1993. Regulation of membrane chloride current in rat bile duct epithelial cells. J. Clin. Invest. 91:319-328.

20. Bruck, R. A., A. Benedetti, M. Strazzabosco, and J. L. Boyer. 1993. Intracellular alkalinization stimulates bile flow and vesicular-mediated exocytosis in IPRL. Am. J. Physiol. 28:G347-G353.

21. Gautam, A., O. C. Ng, and J. L. Boyer. 1987. Isolated rat hepatocyte couplets in short-term culture: structural characteristics and plasma membrane reorganization. Hepatology. 7:216-223.

22. Seglen, P. O. 1976. Preparation of isolated rat liver cells. Methods Cell Biol. 13:29-84.

23. Strazzabosco, M., S. Sakisaka, T. Hayakawa, and J. L. Boyer. 1991. Effect of UDCA on intracellular and biliary pH in isolated rat hepatocyte couplets and perfused livers. Am. J. Physiol. 260:G58-G69.

24. Alvaro, D.,'A. Mennone, and J. L. Boyer. 1993. Effect of ursodeoxycholic acid on intracellular pH regulation in isolated rat bile duct epithelial cells. Am. J. Physiol. 265:G783-G791.

25. Thomas, J. A., R. N. Buchsbaum, A. Zimniack, and E. Racker. 1979. Intracellular $\mathrm{pH}$ measurements in Erlich ascites tumor cells utilizing spectroscopic probes generated in situ. Biochemistry. 18:2210-2218.

26. Wenzl, E., and T. Machen. 1989. Intracellular pH dependence of buffer capacity and anion exchange in the parietal cell. Am. J. Physiol. 257:G741-G747.
27. Weintraub, W. H., and T. E. Machen. 1989. pH regulation in hepatoma cells: roles for $\mathrm{Na}^{+}-\mathrm{H}^{+}$and $\mathrm{Cl}^{-}-\mathrm{HCO}_{3}^{-}$exchange and for $\mathrm{Na}^{+}-\mathrm{HCO}_{3}^{-}$symport. Am. J. Physiol. 257:G317-G327.

28. Boyarsky, G., M. B. Ganz, R. B. Sterzel, and W. F. Boron. 1988. pH regulation in single glomerular mesangial cells. I. Acid extrusion in absence and presence of $\mathrm{HCO}_{3}^{-}$. Am. J. Physiol. 255:C844-C856.

29. Boyarsky, G., M. B. Ganz, R. B. Sterzel, and W. F. Boron. 1988. pH regulation in single glomerular mesangial cells. II. $\mathrm{Na}^{+}$-dependent and -independent $\mathrm{Cl}^{-} / \mathrm{HCO}_{3}^{-}$exchangers. Am. J. Physiol. 255:C857-C869. 30.

31. Corvera, S., J. Huerta-Bahena, J. T. Pelton, V. J. Hruby, D. Trivedi, and J. A. Garcia-Sainz. 1984. Metabolic effects and cyclic AMP levels produced by glucagon, (1- $\mathrm{N}$-Trinitrophenylhistidine,12-homoerginine) glucagon and forskolin in isolated rat hepatocytes. Biochim. Biophys. Acta. 804:434-441.

32. Gray, M. A., J. R. Greenwell, and B. E. Argent. 1988. Secretin-regulated chloride channel on the apical plasma membrane of pancreatic duct cells. $J$. Membr. Biol. 105:131-142.

33. Argent, B. E., S. Arkle, M. E. J. Cullen, and R. Green. 1986. Morphological, biochemical and secretory studies on rat pancreatic ducts maintained in tissue culture. Q. J. Exp. Physiol. 71:633-648.

34. Wangermann, P., M. Wittner, A. Di Stefano, H. C. Henglert, H. J. Lang, E. Schlatter, and R. Greger. 1986. $\mathrm{Cl}^{-}$-channel blockers in the thick ascending limb of the loop of Henle. Structure activity relationship. Pflugers Arch. 407(Suppl.):S128-S141.

35. Meier, P. J., R. G. Knickelbein, R. H. Moseley, J. W. Dobbins, and J. L. Boyer. 1985. Evidence for carrier-mediated chloride/bicarbonate exchange in canalicular rat liver plasma membrane vesicles. J. Clin. Invest. 75:1256-1263.

36. Arias, I. M., and M. Forgac. 1984. The sinusoidal domain of the plasma membrane of rat hepatocytes contains an amiloride-sensitive $\mathrm{Na}^{+} / \mathrm{H}^{+}$antiport. J. Biol. Chem. 259:5406-5408.

37. Renner, E. L., J. R. Lake, B. F. Scharschmidt, B. Zimmerli, and P. J. Meier. 1988. Rat hepatocytes exhibit basolateral $\mathrm{Na}^{+} / \mathrm{HCO}_{3}^{-}$cotransport. J. Clin. Invest. 83:1225-1235.

38. Graf, J., R. M. Henderson, B. Krumpholz, and J. L. Boyer. 1987. Cell membrane and transepithelial voltages and resistances in isolated rat hepatocytes couplets. J. Membr. Biol. 95:241-254.

39. Schworer, C., and G. E. Mortimore. 1979. Glucagon-induced autophagy and proteolysis in rat liver: mediation by selective deprivation of intracellular amino acids. Proc. Natl. Acad. Sci. USA. 76:3169-3173.

40. Hayakawa, T., R. Bruck, O. C. Ng, and J. L. Boyer. 1990. DBcAMP stimulates vesicle transport and HRP excretion in isolated rat liver. Am. J. Physiol. 259:G727-G735.

41. Rothermel, J. D., and L. H. P. Botelho. 1988. A mechanistic and kinetic analysis of the interaction of the diastereomers of adenosine $3^{\prime}, 5^{\prime}$-(cyclic) phosphorothioate. Biochem. J. 251:757-762.

42. Jarvest, R. L., G. Lowe, J. Baraniak, and W. J. Stec. 1982. A stereochemical investigation of the hydrolysis of cyclic AMP and the (Sp)- and (Rp)diastereoisomers of adenosine cyclic 3':5'-phosphorothioate by bovine heart and baker's-yeast cyclic AMP phosphodiesterases. Biochem. J. 203:461-470.

43. Rothermel, J. D., B. Jastorff, and L. H. P. Botelho. 1984. Inhibition of glucagon-induced glycogenolysis in isolated rat hepatocytes by the Rp diastereomer of adenosine $3^{\prime}, 5^{\prime}$-(cyclic) phosphorothioate. J. Biol. Chem. 259:81518155.

44. Chijiwa, T., A. Mishima, M. Hagiwara, M. Sano, K. Hayashi, T. Inowe, K. Naito, T. Toshioka, and H. Hidaka. 1990. Inhibition of forskolin-induced neurite outgrowth and protein phosphorylation by a newly synthesized selective inhibitor of cyclic AMP-dependent protein kinase, $N$-[2-( $p$-bromocinnamyl-amino)ethyl]-5-isoquinolinesulfonamide (H-89), of $\mathrm{PC12D}$ pheochromocytoma cells. J. Biol. Chem. 265:5267-5272.

45. Sellinger, M., S. A. Weinman, R. M. Henderson, A. Zweifach, J. L. Boyer, and J. Graf. 1992. Anion channels in rat liver canalicular plasma membranes reconstituted into planar lipid bilayers. Am. J. Physiol. 262:G1027-G1032.

46. Reuss, L. 1989. Ion transport across gallbladder epithelium. Physiol. Rev. 69:503-545.

47. Krapf, R., and R. J. Alpern. 1993. Cell pH and transepithelial $\mathrm{H} / \mathrm{HCO}_{3}$ transport in the renal proximal tubule. J. Membr. Biol. 131:1-10.

48. Corasanti, J. G., N. D. Smith, E. G. Gordon, and J. L. Boyer. 1989. Protein kinase $\mathrm{C}$ agonists inhibit bile secretion independently of effects on the microcirculation in the isolated perfused rat liver. Hepatology. 10:8-13.

49. Heyworth, C. M., S. P. Wilson, D. J. Gawler, and M. D. Houslay. 1985 The phorbol ester TPA prevents the expression of both glucagon desensitisation and the glucagon-mediated block of insulin stimulation of the peripheral plasma membrane cyclic AMP phosphodiesterase in rat hepatocytes. FEBS (Fed. Eur. Biochem. Soc.) Lett. 187:196-200.

50. Soleimani, M., G. A. Lesoine, J. A. Bergman, and T. D. McKinney. 1991. A pH modifier site regulates activity of the $\mathrm{Na}^{+}: \mathrm{HCO}_{3}^{-}$cotransporter in basolateral membranes of kidney proximal tubules. J. Clin. Invest. 88:1135-1140.

51. Fehlmann, M., and P. Freychet. 1981. Insulin and glucacon stimulation of $\left(\mathrm{Na}^{+}-\mathrm{K}^{+}\right)$-ATPase transport activity in isolated rat hepatocytes. J. Biol. Chem. 256:7449-7453. 